Review

\title{
Essential Role of the 14q32 Encoded miRNAs in Endocrine Tumors
}

\author{
Lilla Krokker ${ }^{1}$, Attila Patócs 1,2,3 and Henriett Butz 1,2,3,*(D) \\ 1 Department of Laboratory Medicine, Semmelweis University, H-1089 Budapest, Hungary; \\ krkkr.lilla@gmail.com (L.K.); patocs.attila@med.semmelweis-univ.hu (A.P.) \\ 2 Hereditary Cancers Research Group, Hungarian Academy of Sciences-Semmelweis University, \\ H-1089 Budapest, Hungary \\ 3 Department of Molecular Genetics, National Institute of Oncology, H-1122 Budapest, Hungary \\ * Correspondence: butz.henriett@med.semmelweis-univ.hu
}

check for

updates

Citation: Krokker, L.; Patócs, A.; Butz, H. Essential Role of the 14q32 Encoded miRNAs in Endocrine Tumors. Genes 2021, 12, 698. https:// doi.org/10.3390/genes12050698

Academic Editor: Tamas I. Orban

Received: 19 March 2021

Accepted: 5 May 2021

Published: 8 May 2021

Publisher's Note: MDPI stays neutral with regard to jurisdictional claims in published maps and institutional affiliations.

Copyright: (c) 2021 by the authors. Licensee MDPI, Basel, Switzerland. This article is an open access article distributed under the terms and conditions of the Creative Commons Attribution (CC BY) license (https:// creativecommons.org/licenses/by/ $4.0 /)$.

\begin{abstract}
Background: The 14q32 cluster is among the largest polycistronic miRNA clusters. miRNAs encoded here have been implicated in tumorigenesis of multiple organs including endocrine glands. Methods: Critical review of miRNA studies performed in endocrine tumors have been performed. The potential relevance of 14q32 miRNAs through investigating their targets, and integrating the knowledge provided by literature data and bioinformatics predictions have been indicated. Results: Pituitary adenoma, papillary thyroid cancer and a particular subset of pheochromocytoma and adrenocortical cancer are characterized by the downregulation of miRNAs encoded by the 14q32 cluster. Pancreas neuroendocrine tumors, most of the adrenocortical cancer and medullary thyroid cancer are particularly distinct, as $14 \mathrm{q} 32$ miRNAs were overexpressed. In pheochromocytoma and growth-hormone producing pituitary adenoma, however, both increased and decreased expression of $14 q 32$ miRNAs cluster members were observed. In the background of this phenomenon methodological, technical and biological factors are hypothesized and discussed. The functions of $14 \mathrm{q} 32 \mathrm{miRNAs}$ were also revealed by bioinformatics and literature data mining. Conclusions: 14q32 miRNAs have a significant role in the tumorigenesis of endocrine organs. Regarding their stable expression in the circulation of healthy individuals, further investigation of $14 \mathrm{q} 32$ miRNAs could provide a potential for use as biomarkers (diagnostic or prognostic) in endocrine neoplasms.
\end{abstract}

Keywords: miRNA; 14q32; miRNA cluster; DLK1-MEG3 locus; endocrine tumor; pituitary adenoma; adrenocortical cancer; neuroendocrine tumor; pheochromocytoma; thyroid cancer

\section{Introduction}

MicroRNAs (miRNAs) are single-stranded, small ( 17-22 nucleotide long), protein non-coding RNA molecules that regulate gene expression post-transcriptionally by RNA interference. According to the canonical miRNA biogenesis, the mature miRNA is generated from a hairpin RNA precursor molecule produced by RNA polymerase II or III [1].

After biogenesis, the mature miRNA incorporates into a protein complex called miRISC (miRNA-induced silencing complex) [2]. In the miRISC complex miRNAs lead to translational repression, mRNA destabilization or mRNA cleavage through miRNA-mRNA interaction via base complementarity. MiRNAs target mRNAs mainly at $3^{\prime}$ untranslated regions but even the coding sequence or $5^{\prime}$ UTR have been described to be miRNA target regions [2]. Recently, it has been discovered that in some particular cases miRNAs can even enhance gene expression [2].

Approximately $30-50 \%$ of all protein-coding genes are thought to be controlled by miRNAs [3]. As one miRNA targets several transcripts, and one mRNA is regulated by numerous miRNAs, the net physiological outcome is the result of a miRNA-target network. The role of miRNAs is primarily considered to set the gene expression to an optimal level as an adaptive process called "fine tuning" [4]. 
MiRNAs have been shown to be involved in the control of many physiological and pathophysiological processes, such as proliferation, differentiation, metabolism and apoptosis through the modulation of target gene expression. Altered miRNA expression has been identified in several endocrine diseases including neoplasms [5,6]. Depending on their target molecules, miRNAs are considered as oncomiRs or tumor suppressor miRNAs, and therefore they are often considered potentially useful biomarkers. MiRNAs are highly tissue-specific, and they may be unique identifiers of certain tumor types, even having different effects in different cell/tissue types.

The $14 \mathrm{q} 32$ miRNA cluster is among the largest polycistronic clusters comprising almost a hundred small non-coding RNAs, including a significant number of miRNAs [7]. MiRNAs located in this region cover over $5 \%$ of the known human miRNA genes [8,9].

The 14q32 region is called the DLK1-DIO3 domain or DLK1-MEG3 cluster. Indeed, this cluster contains protein-coding (Delta-like 1 (DLK1), Deiodinase Iodothyronine Type III (DIO3) and Retrotransposon-like Gene 1 (RTL1)) and nonprotein-coding genes (ncRNAs, such as Maternally Expressed Gene 3 (MEG3), Maternally Expressed Gene 8 (MEG8) and RTL1 antisense (RTL1-AS)), small nucleolar RNAs (snoRNAs) and miRNAs. This approximately 300 kilobase miRNA region can be divided into two parts: cluster A and cluster B. Cluster A includes MEG3 and RTL1 genes, while cluster B can be found $5^{\prime}$ from MEG9 and DIO3 genes (Figure 1A).
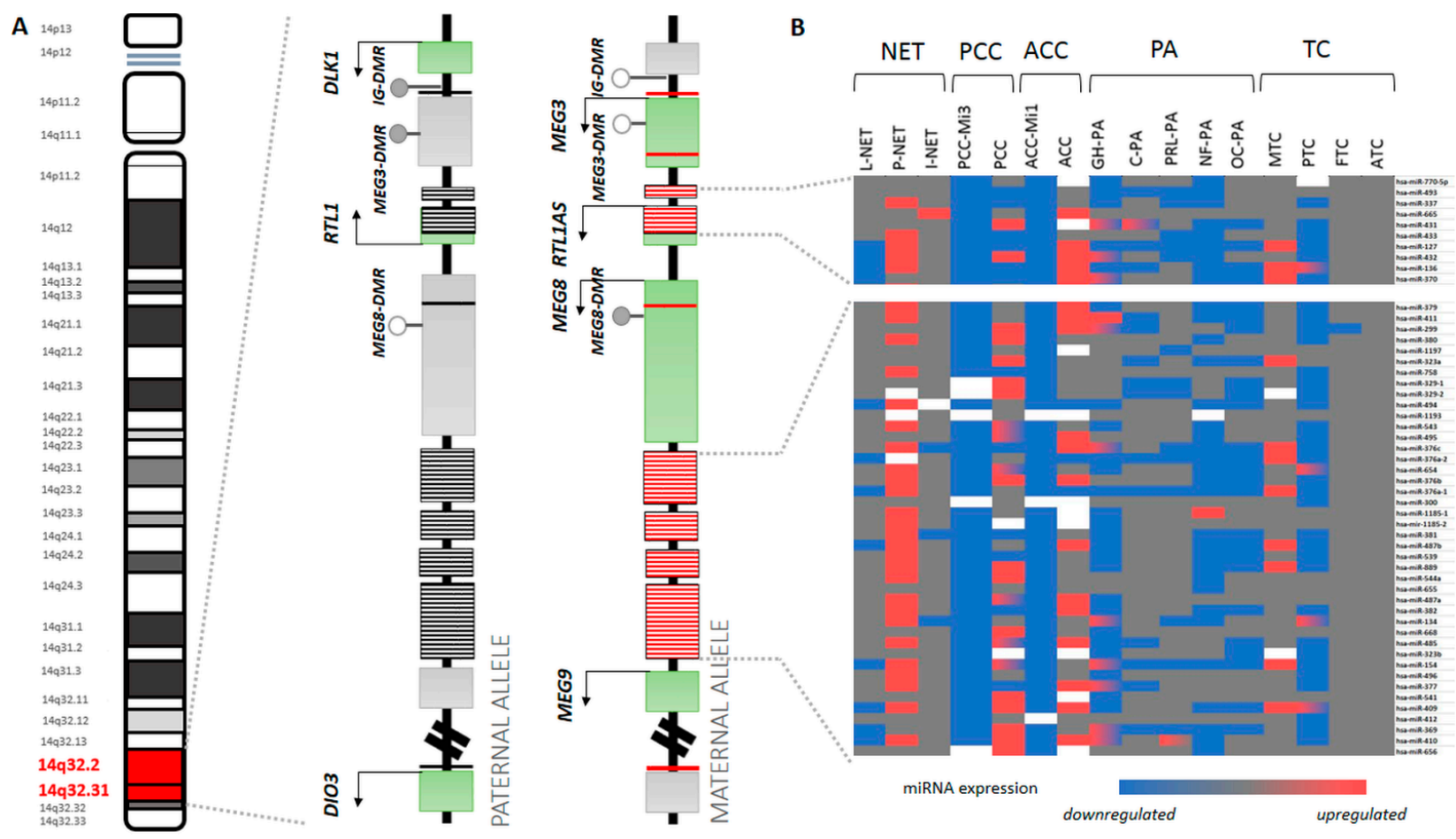

Figure 1. The imprinted 14q32 region. (A) On the paternal and maternal alleles middle: exons colored by grey indicate imprinted genes, exons colored by green indicate transcriptionally active state. DMR status is presented by grey (methylated) and white (unmethylated) circles. Black stripes represent imprinted miRNA genes, red stripes represent transcriptionally active miRNA genes. (B) On the heatmap (right): Representative expressional change of 14q32 miRNAs in endocrine tumors (downregulation and overexpression are presented compared to physiological, monoallelic expression. Heatmap was constructed using the data of 59 studies (see details in the methods section)). MiRNAs indicated on the heatmap are listed in Table 1 indicating the exact chromosomal localization. Colors indicate expression (blue color was used for low and red for high expression, grey represents monoallelic expression, white: no data available).

As miRNA expression can be influenced by several factors, Goossens and colleagues investigated the effect of the most common confounding factors: sex and age on the miRNA expression profile of this region [10]. The finding that 14q32 miRNA expression 
did not differ between men and women, and that no correlation with age was observed, highlighted the importance of this miRNA cluster in cell biology [10]. This was further supported by others who described that the $14 \mathrm{q} 32$ maternally imprinted locus was a major source of longitudinally stable circulating miRNAs as measured by small RNA sequencing of healthy individuals [11]. In addition, the serum level of 14q32 miRNAs was not significantly affected by common confounders such as age, body mass index (BMI) or time of centrifugation, nor alternative methods of expression data normalization [11].

$14 q 32$ miRNAs are frequently described deregulated in human diseases and cancers [12-14]. In line with the finding that miRNAs are highly tissue-specific [7,15], 14q32 miRNAs are considered both oncogenic and tumor suppressing depending on cell type $[14,16]$.

The expression of $14 \mathrm{q} 32$ genes is regulated by genomic imprinting. The differential expression of alleles inherited from a mother or father at the genomic imprinted loci is realized by different methylation. The regulatory loci of the methylated nucleotides are called differentially methylated regions (DMRs). Differential methylation patterns at DMRs provide monoallelic expression from either maternal or paternal allele. Generally, imprinted genes have a key role in regulating growth and other physiological functions during embryonic development. Germline deletions and uniparental disomy of this locus in humans associate with developmental abnormalities and dysmorphism, suggesting that the 14q32 locus might have significant importance in development [17-24]. As several maternally imprinted genes limit growth during development, they usually possess a tumor-suppressor role in human cancer [25]. In line with this, the DLK1-MEG3 cluster was frequently affected by allelic loss or epigenetic changes in various cancers [26-29]. In the $14 \mathrm{q} 32$ region, the paternally expressed protein coding genes are DLK1,DIO3 and RTL1 [30]. From the maternal allele MEG3, MEG8 and RTL1-AS long noncoding RNAs are expressed [9,31]. This imprinted gene expression of this locus is under the control of three DMRs [20,32]: a DMR located $11 \mathrm{~kb}$ upstream of MEG3 (also called intergenic differentially methylated region, IG DMR), a DMR $1.3 \mathrm{~kb}$ upstream of the MEG3 transcription start site (MEG3-DMR) and a DMR found in the DLK1 promoter (DLK1-DMR) [33] (Figure 1A).

The MEG3-IG DMR, which is methylated on the paternal allele and unmethylated on the maternal allele, functions as the primary imprinting control region (ICR) for the entire locus during development [34], whereas MEG3-DMR serves as the principal regulator in adult tissues [20]. This imprinted methylation pattern provides the reciprocal expression of DLK1 and MEG3.

Accordingly, 14q32 miRNAs are also involved in the imprinting regulation $[7,35]$ and altered 14q32 miRNA expression have been described in several diseases including malignancies [36-41]. Several studies have shown downregulation of miRNAs from the $14 \mathrm{q} 32$ region in different types of cancer, such as ovarian, breast, prostate, bladder, osteosarcoma, and gastrointestinal stromal, with significant correlations to poor prognosis and aggressiveness [42-48]. The tumor suppressor role has been recognized in several of the downregulated 14q32 miRNAs through targeting key oncogenes in glioblastoma, neuroblastoma, metastatic lung cancer, hepatic cancer and rhabdomyosarcoma [25,49-51]. In contrast, miRNAs from the 14q32 region may act as oncogenes as well [52-54], suggesting that these miRNAs may have different biological roles depending on the tissue of origin and genetic background.

$14 \mathrm{q} 32$ miRNAs also influence prognosis of various cancers. Oshima et al. presented that the expression of $14 \mathrm{q} 32$ miRNAs was a favorable prognostic factor in patients with metastatic cancer [41]. Based on studies of Lussier et al. 2011 and 2012, the term oligomiR was introduced $[55,56]$. There were miRNAs differentially expressed between patients with limited numbers and slow progression of metastases (oligometastases) compared to patients with widely disseminated or rapidly progressive metastatic disease $[55,56]$. Interestingly, miRNAs encoded in the 14q32 were significantly enriched among oligomiRs [22]. Additionally, 14q32 miRNAs suppressed lung and liver metastases and correlated with improved clinical outcomes. In osteosarcoma 14q32 miRNAs also had prognostic significance, as an inverse correlation was described between aggressive tumor behavior (increased 
metastatic potential and accelerated time to death) and the residual expression of this miRNA locus [47].

Despite of the relevance of 14q32 miRNAs in other malignancies, regarding endocrine tumors, there has no comprehensive review published about the role of 14q32 miRNA cluster. In this work, the authors aimed to collect high-throughput miRNA studies performed in endocrine tumor samples, to extract the role and potential relevance of $14 \mathrm{q} 32$ miRNAs through investigating miRNA targets and to integrate the knowledge provided by literature data and bioinformatics predictions.

\section{Materials and Methods}

Literature mining was performed using Pubmed database using the following keywords: "14q32" or "miRNA" or "DLK1-MEG3" and combined with either of "endocrine tumors", "neuroendocrine tumor", "pituitary adenoma", "adrenocortical tumor", "pheochromocytoma" or "thyroid cancer". Publication focused on 14q32 miRNAs regarding endocrine tumors, and high-throughput miRNA profiling studies of endocrine tumors were selected to construct an expression heatmap (Figure 1B, Table 1). Downregulated/overexpressed miRNAs were included when at least one study reported it significantly without conflict (conflict was considered when another study reported the opposite change). When conflicting information was observed between studies, gradient colour was used. Unfortunately, as in many studies, raw data were not available and only the significant lists were reported; only "downregulated" and "overexpressed" characteristics could be considered irrespectively of fold change. The heatmap itself was generated in Microsoft Excel (Microsoft Office Professional Plus 2013).

Table 1. MiRNA studies used for heatmap generation.

\begin{tabular}{|c|c|c|c|}
\hline \multicolumn{2}{|c|}{ Tumor Type } & \multirow{2}{*}{$\begin{array}{c}\text { Study } \\
\text { Yoshimoto et al., 2018 [57] }\end{array}$} & \multirow{2}{*}{$\begin{array}{c}\text { miRNA Profiling Platform } \\
\text { microarray }\end{array}$} \\
\hline \multirow[t]{14}{*}{ NET } & Lung & & \\
\hline & & Mairinger et al., 2014 [58] & TaqMan array \\
\hline & & Deng et al., 2014 [59] & microarray \\
\hline & & Rapa et al., 2015 [60] & PCR array \\
\hline & & Wong et al., 2020 [61] & NGS \\
\hline & Pancreas & Zimmermann et al., 2018 [62] & TaqMan array \\
\hline & & Roldo et al., 2006 [63] & microarray \\
\hline & & Jiang et al., 2015 [64] & PCR array \\
\hline & & Zhou et al., 2016 [65] & microarray (GSE43796) reanalysis \\
\hline & & Lee et al., 2015 [66] & Nanostring nCounter \\
\hline & small intestinal & Yoshimoto et al., 2018 [57] & microarray \\
\hline & & Arvidsson et al., 2018 [67] & microarray \\
\hline & & Li et al., 2013 [68] & microarray \\
\hline & & Miller et al., 2016 & Nanostring nCounter \\
\hline \multirow[t]{5}{*}{ PPGL } & & Castro-Vega et al., 2015 [69] & NGS \\
\hline & & Tömböl et al., 2010 [70] & TaqMan array \\
\hline & & de Cubas et al., 2013 [71] & microarray \\
\hline & & Meyer-Rochow et al., 2010 [72] & microarray \\
\hline & & Calsina et al., 2019 [73] & individual qPCR \\
\hline \multirow[t]{4}{*}{$\mathrm{ACC}$} & & Tömböl et al., 2009 [74] & TaqMan array \\
\hline & & Chabre et al., 2012 [54] & microarray \\
\hline & & Özata et al., 2011 [75] & microarray \\
\hline & & Assié et al., 2014 [76] & NGS \\
\hline
\end{tabular}


Table 1. Cont.

\begin{tabular}{|c|c|c|c|}
\hline \multicolumn{2}{|c|}{ Tumor Type } & Study & miRNA Profiling Platform \\
\hline \multirow[t]{22}{*}{ Pituitary } & $\mathrm{GH}$ & Mao et al., 2010 [77] & microarray \\
\hline & & D'Angelo et al., 2012 [78] & microarray \\
\hline & & Bottoni et al., 2007 [79] & microarray \\
\hline & & Butz et al., 2009 [80] & TaqMan array \\
\hline & & Cheunsuchon et al., 2011 [81] & individual qPCR \\
\hline & & He et al., 2019 [82] & NGS \\
\hline & $\mathrm{ACTH}$ & Gentilin et al., 2013 [83] & individual TaqMan assay \\
\hline & & Amaral et al., 2009 [84] & individual TaqMan assay \\
\hline & & Stilling et al., 2010 [85] & microarray \\
\hline & & Cheunsuchon et al., 2011 [81] & individual qPCR \\
\hline & PRL & He et al., 2019 [82] & NGS \\
\hline & & Müssnich et al., 2015 [86] & microarray \\
\hline & & Chen et al., 2012 [87] & NGS \\
\hline & & Cheunsuchon et al., 2011 [81] & individual qPCR \\
\hline & NFPA & He et al., 2019 [82] & NGS \\
\hline & & Darvasi et al., 2019 [88] & NGS, TaqMan array and microarray \\
\hline & & Butz et al., 2011 [89] & TaqMan array \\
\hline & & Liang et al., 2015 [90] & individual qPCR \\
\hline & & Cheunsuchon et al., 2011 [81] & individual qPCR \\
\hline & & Müssnich et al., 2015 [86] & microarray \\
\hline & & Bottoni et al., 2007 [79] & microarray \\
\hline & OC & Krokker et al., 2019 [91] & NGS \\
\hline \multirow[t]{25}{*}{ Thyroid } & MTC & Lassalle et al., 2016 [92] & microarray \\
\hline & & Hudson et al., 2013 [93] & Taqman array \\
\hline & & Nikiforova et al., 2008 [94] & Taqman array \\
\hline & PTC & Geraldo et al., 2017 [95] & $\begin{array}{c}\text { NGS (obtained from The Cancer } \\
\text { Genome Atlas dataset) }\end{array}$ \\
\hline & & Rosignolo et al., 2017 [96] & Taqman array \\
\hline & & Tetzlaff et al., 2007 [97] & microarray \\
\hline & & Linwah et al., 2011 [98] & microarray \\
\hline & & Jacques et al., 2013 [99] & microarray \\
\hline & & Lassalle et al., 2011 [100] & microarray \\
\hline & & Mancikova et al., 2015 [101] & NGS \\
\hline & & Peng et al., 2014 [102] & microarray \\
\hline & & Riesco-Eizaguirre et al., 2015 [103] & NGS \\
\hline & & Saiselet et al., 2015 [104] & NGS \\
\hline & & Swierniak et al., 2013 [105] & NGS \\
\hline & FTC & Nikiforova et al., 2008 [94] & TaqMan array \\
\hline & & Rossing et al., 2012 [106] & microarray \\
\hline & & Dettmer et al., 2013 [107] & Taqman array \\
\hline & & Jacques et al., 2013 [99] & microarray \\
\hline & & Lassalle et al., 2011 [100] & microarray \\
\hline & & Mancikova et al., 2015 [101] & NGS \\
\hline & & Wojtas et al., 2014 [108] & microarray \\
\hline & ATC & Hébrant et al., 2014 [109] & microarray \\
\hline & & Visone et al., 2007 [110] & microarray \\
\hline & & Boufraqech et al., 2015 [111] & microarray \\
\hline & & Braun et al., 2010 [112] & microarray \\
\hline
\end{tabular}

ACC: adrenocortical carcinoma; ACTH: corticotroph adenoma; ATC: anaplastic thyroid cancer; FTC: follicular thyroid carcinoma; GH: growth hormone; MTC: medullary thyroid carcinoma; NET: neuroendocrine tumor; NFPA: nonfunctional pituitary adenoma; OC: oncocytoma; PPGL: pheochromocytoma-paraganglioma; PRL: prolactin; PTC: papillary thyroid carcinoma.

Also, miRbase MIMAT IDs of dominant mature 14q32 miRNAs were used for bioinformatics analysis (http:/ / www.mirbase.org/, access date: 25 February 2021). Pathway analysis for 14q32 miRNA targets by gene set enrichment analysis for KEGG pathways was 
performed using DIANA TOOLS miRPath v.3 following target prediction by microT-CDS algorithm (http:/ / snf-515788.vm.okeanos.grnet.gr/, access date: 25 February 2021). Gene ontology was assessed using miRDB Target Ontology Analysis module by selecting enrichment for Biological Process and Molecular Function (http://mirdb.org/ontology.html, access date: 25 February 2021).

\section{3. miRNAs in Endocrine Tumors}

\subsection{Neuroendocrine Tumors (NET)}

Neuroendocrine tumors (NETs) are a group of heterogeneous neoplasms arising from neuroendocrine cells throughout the body (most commonly from the gastrointestinal system or lungs). Although gastro-entero-pancreatic NETs (GEP-NETs) represent less than $1 \%$ of all digestive system cancers it consists $7-21 \%$ of all neuroendocrine neoplasms [113]. Lung NETs originate from pulmonary neuroendocrine cells accounting for approximately $25 \%$ of primary lung neoplasms and they are classified into typical carcinoids (TCs, well differentiated, low-grade), atypical carcinoids (ACs, well-differentiated, intermediategrade), large cell neuroendocrine carcinomas (LCNECs, poorly differentiated, high-grade) and small cell lung cancer (SCLCs, poorly differentiated, high-grade) subtypes [114].

In GEP-NETs tissue, however, several miRNA studies have been published $[115,116]$, scarce information was available regarding 14q32 miRNA profiles. In the study by Jiang et al., 29 overexpressed miRNAs derived from 14q32 were identified in insulinomas vs. normal islets, and several showed high abundance in insulinoma cells $[64,117]$. Unfortunately, this finding was not reported by others [65]. MiRNAs of this region were associated with prognosis, since miR-485-3p encoded at $14 q 32$ region was significantly elevated in the metastatic tumors compared to the primary pancreatic NETs (pNET) (Table 2) [66]. Investigating small intestine (siNET) and colorectal NET, studies did not identify differentially expressed miRNAs encoded at 14q32 [118-121]. However, similar to pNET, miRNAs were linked to progression as 14q32 encoded miR-494 was significantly overexpressed in metastases compared to primary siNET [68]. Interestingly, by using miRNA expression profiling, Yoshimoto et al. described a similar pattern of miRNAs of carcinoids of the lung and gastrointestinal NETs, which was different from adenocarcinomas, small cell lung cancers and normal mucosal cells, suggesting a common origin of systemic carcinoids/NETs [57]. Also, miR-494 was downregulated in carcinoid vs. adenocarcinoma/normal tissue group [57]. Regarding lung NET types, Rapa et al. detected several 14q32 miRNAs (miR-409-3p, miR409-5p, miR-376a, miR-376b, miR-381) upregulated in typical compared to atypical lung carcinoids [60]. Measured on 46 lung carcinoid tumors, a more extensive list of miRNAs expressed from 14q32 cluster detected as downregulated compared to their adjacent normal tissue pair samples by Deng et al. (miR-487b, miR-410, miR-369, miR-376a, miR-432, miR-409, miR-494, miR-136, miR-370, miR-127 and miR-154) [59].

Table 2. Summary of the most important dysregulated, 14q32 encoded miRNAs in different endocrine neoplasms.

\begin{tabular}{|c|c|}
\hline \multicolumn{2}{|c|}{ NET } \\
\hline miR-485-3p & increased in the metastatic tumors compared to the primary pNET \\
\hline $\operatorname{miR}-494$ & $\begin{array}{l}\text { overexpressed in metastases compared to primary siNET } \\
\text { downregulated in carcinoid vs. adenocarcinoma/normal lung tissue }\end{array}$ \\
\hline miR-376a, miR-376b, miR-381, miR-409-3p, miR-409-5p, & upregulated in typical compared to atypical lung carcinoids \\
\hline $\begin{array}{l}\text { miR-127, miR-136, miR-154, miR-369, miR-370, miR-376a, miR-410, } \\
\text { miR-432, miR-409, miR-487b, miR-494 }\end{array}$ & downregulated in lung carcinoid compared to adjacent normal tissue \\
\hline miR-409-3p, miR-409-5p, miR-411, miR-431-5p, miR-485 and miR-539 & $\begin{array}{l}\text { downregulated in metastatic carcinoids compared to non-metastatic } \\
\text { lung NET }\end{array}$ \\
\hline miR-127, miR-136, miR-154, miR-485, miR-770-5p & negative correlation with tumor biology of lung NET \\
\hline
\end{tabular}


Table 2. Cont.

\section{PPGL}

miR-493-5p

miR-127-3p, miR-136, miR-154-3p/5p, miR-323a-3p, miR-337-5p/-3p,

miR-369-5p, miR-370, miR-376a-5p, miR-376c, miR-377, miR-382,

miR-409-5p, miR-410, miR-485-3p és 5p, miR-487a, miR-495, miR-539, miR-543, miR-758, miR-889

miR-154-3p, hsa-miR-369-5p, hsa-miR-485-5p, hsa-miR-487a, hsa-miR-495, hsa-miR-543, hsa-miR-656, hsa-miR-889

miR-541

miR-154, miR-337-3p

miR-409-3p, miR-369-3p

miR-431 commonly downregulated in all PCC molecular subtypes (based on germline mutation)

downregulation in MAX-related PPGLs and a subset of sporadic PCC

overexpression in TMEM127-related PPGL cases

overexpressed in VHL-related PCC vs. sporadic PCC, decreased expression in recurrent tumors compared to primary tumors

upregulated in a subset of metastatic PCC compared to non-metastatic cases

downregulation in a subset of metastatic PCC compared to benign PCC upregulated in malignant tumors compared to benign Adrenocortical Tumors

miR-370 overexpressed in APA compared to non-APA adrenal tumors

miR-299 downregulated in KCNJ5 mutant APA vs. non-KCNJ5 mutant samples

14q32 miRNA cluster whole miRNA cluster downregulation in Mi1 subset of ACC

miR-136, miR-127-3p, miR-487b, miR-376c and miR-432 overexpressed in ACC compared to normal adrenal cortex miR-376a, miR-376b overexpression in ACC vs. ACA

miR-376a

downregulated in ACC vs. NF adenoma, CPA and normal adrenal cortex

miR-299-5p, miR-485-5p

overexpressed in ACC vs. NF adenoma, CPA and normal adrenal cortex

miR-370, miR-376a, miR-376b, miR-376c, miR-377, miR-379, miR-382, miR-411, miR-487a, miR-494, miR-495

miRNA-665

downregulated in non-aggressive ACC as compared to aggressive ones

$\mathrm{miR}-431$

overexpressed in ACC as compared to benign adrenocortical tumors implicated in adjuvant therapy response in ACC

\section{PitNET}

miR-127-3p, miR-154, miR-329, miR-337, miR-369-5p, miR-376c, miR-432, miR-433

downregulated in PRL adenoma vs. normal miR-410 overexpressed in PRL adenoma vs. normal

miR-411-3p overexpressed in GH adenoma vs. normal

miR-381, miR-654-3p downregulated in GH adenoma vs. normal

miR-127, miR-134, miR-136, miR-154, miR-323a, miR-337, miR-369,

miR-370, miR-376a-1, miR-376a-2, miR-376b, miR-376c, miR-379,

miR-380, miR-381, miR-382, miR-409, miR-410, miR-411, miR-431,

miR-432, miR-433, miR-487b, miR-493, miR-494, miR-495, miR-539, miR-543, miR-544a, miR-654, miR-656, miR-770-5p, miR-889

$$
\text { miR-1185-1-3p }
$$

downregulated in NF adenoma vs. normal

miR-127-3p, miR-136, miR-154, miR-299-5p, miR-323-5p, miR-329,

miR-369-3p, miR-369-5p, miR-376c, miR-377, miR-411-3p, miR-431-3p, miR-433, miR-493

miR-431, miR-493

upregulated in NF adenoma vs. normal

downregulated in corticitroph adenoma vs. normal

overexpressed in corticotroph carcinoma vs. adenoma

miR-127, miR-136, miR-154, miR-299, miR-323a, miR-323b, miR-329-1

miR-329-2, miR-369, miR-370, miR-376a-1, miR-376a-2, miR-376b,

miR-376c, miR-379, miR-381, miR-382, miR-409, miR-411, miR-431, miR-485, miR-487b, miR-494, miR-539, miR-654, miR-889

\section{Thyroid Carcinoma}

miR-9, miR-127, miR-136, miR-154, miR-323, miR-376a,c, miR-370, miR-487b

upregulated in MTC vs. normal 
Table 2. Cont.

\begin{tabular}{cc}
\hline miR-134, miR-136, miR-409, miR-654 & overexpressed in PTC \\
\hline miR-134, miR-300, miR-379, miR-382, miR-494-3p, miR-494-5p, miR-495 & downregulated in PTC \\
\hline miR-654-3p & inverse correlation with PTC progression \\
\hline
\end{tabular}

ACA: adrenocortical adenoma; ACC: adrenocortical carcinoma; APA: aldosterone producing adenoma; CPA: cortisol producing adenoma; FTC: follicular thyroid carcinoma; GH: growth hormone; KCNJ5: potassium inwardly rectifying channel subfamily J member 5; MAX: MYC associated factor X; MTC: medullary thyroid carcinoma; NET: neuroendocrine tumor; NF: nonfunctional; PCC: pheochromocytoma; pNET: pancreatic neuroendocrine tumor; PPGL: pheochromocytoma-paraganglioma; PRL: prolactin; PTC: papillary thyroid carcinoma; siNET: small intestinal neuroendocrine tumor; TMEM127: transmembrane protein 127; VHL: von Hippel-Lindau tumor suppressor.

Several studies evaluated the role of miRNAs as prognostic markers [116]. Among others, miR-409-3p, miR-409-5p, miR-431-5p, miR-411, miR-485 and miR-539 encoded at 14q32 were significantly downregulated in metastatic carcinoids compared to non-metastatic lung NETs, while miR-409-3p, miR-409-5p and miR-431-5p were found downregulated in cases with vascular invasion $[60,116]$.

Also among 14q32 miRNAs, the expression of miR-127, miR-136, miR-154, miR-485, miR-770-5p showed negative correlation with tumor biology of lung NET, and miR-377* was identified, showing a significant impact on survival time [58].

A recent study reported that among the most abundant miRNAs in lung NET types, miR-127 encoded at 14q32 showed high expression in typical carcinoids tumors [61]. Besides, no $14 \mathrm{q} 32$ miRNA was identified as discriminatory miRNAs characteristic to typical carcinoid, atypical carcinoid, small cell lung cancer or large cell neuroendocrine carcinomas in the study of Wong et al. [61].

\subsection{Pheochromocytoma-Paraganglioma (PPGL)}

The rare pheochromocytomas (PCC) and paragangliomas (PGL) (together PPGL, incidence 1-8:1,000,000) arise from the same type of neural crest tissue of the sympathetic and parasympathetic paraganglia [122]. While tumors of the adrenal medulla are called PCCs, neoplasms developing from the head and neck, thoracic, abdominal or pelvic regions paraganglia are referred as PGLs. These tumors are usually benign and the 10-year overall survival is around $\sim 96 \%$, but $10 \%$ of PCC and even $40 \%$ of PGL occur as metastatic disease resulting in a 5-year survival below 50\% [122]. Interestingly, PPGL has an extremely high rate of genetic susceptibility, when a germline mutation leads to autosomal dominant genetic syndromes (multiple endocrine neoplasia type 2A and 2B caused by RET mutations, von Hippel Lindau syndrome due to VHL mutations, neurofibromatosis type 1 with NF1 mutations or hereditary PG syndrome caused by mutations of succinate dehydrogenase (SDH) genes, PPGL genes including KIF1b, PHD2, TMEM127, MAX, FH, MDH2, GOT2 and SLC25A11 [123]. Unfortunately, there are neither clear histopathological signs of malignant behavior or efficient therapy for malignant PPGL. Therefore, miRNAs have been good candidates being potential biomarkers.

Expectedly, miRNA profile in different genetic subtypes was also distinct and based on a high-throughput miRNA profiling $[70,72,124]$ several 14q32 miRNAs were dysregulated in PPGL [71]. 14q32 encoded miR-493* was commonly downregulated in all molecular subtypes based on germline mutation [71]. The 14q32 miRNA profile (20 miRNAs) showed significant downregulation in MAX-related PPGLs and a subset of sporadic PC samples as well [71]. In TMEM127-related cases overexpression of eight 14q32 miRNAs were detected [71]. MiR-541 was found significantly overexpressed in VHL-related PCCs vs. sporadic counterparts, and these miRNAs had a lower level of expression in recurrent tumors compared to primary PCC [70]. As hypermethylation of DLK-MEG3 locus was reported in approximately 10\% of PCC samples [69], the pathogenic role of downregulated miRNAs located here was also proposed [125]. Indeed, in a comprehensive multi-omic approach, miRNA profiling by next generation sequencing (NGS) revealed 7 homogeneous subgroups of PCC. PCC samples of the Mi1,2 and Mi4-7 clusters exhibited higher 14q32 miRNA expression compared to Mi3 [69], while Mi3 subgroup was characterized by a strong silencing of the imprinted DLK1-MEG3 cluster. In this study 15 of 17 tumors belong- 
ing to cluster Mi3 displayed loss-of-heterozygosity (LOH) at the 14q32 locus harboring DLK1-MEG3. The authors hypothesized that the loss of the maternal unmethylated allele might explain the repression of this imprinted miRNA cluster that was also supported by the methylation analysis of MEG3 promoter [69]. Interestingly, PCC samples belonging to this Mi3 cluster were not associated with any germline mutation (they were all sporadic tumors) and they belonged to a distinct mRNA expression cluster (C2B) [69]. In line with these results, another large-scale study found the upregulation of miR-154, miR-337-3p in a subset of metastatic PCC compared to non-metastatic cases [73]. The downregulation of miR-409-3p, miR-369-3p was also identified in a different subset of metastatic tumors compared to benign ones [73]. In another study comparing benign and malignant cases, miR-431 was detected as upregulated in malignant tumors [72].

\subsection{Adrenocortical Tumors}

In aldosterone producing adenomas (APA), no differentially expressed miRNAs encoded at 14q32 were detected [126-128]. Interestingly, another study identified miR-410 and miR-433 as Wnt/ $\beta$-catenin signaling regulatory miRNAs with significantly different expression between APA and peritumoral adrenal tissues using microarray [129]. A study investigating APA compared to non-APA adrenal tumors (adrenocortical adenoma (ACA), subclinical hypercortisolism (SH), non-functioning adrenal adenoma (NF)) identified miR370 as overexpressed in aldosterone producing tumors. Also, similar to pheochromocytoma, in APA miRNA signature was also reflected in germline mutation carrier status [130], and miR-299 from locus 14q32 was found downregulated in KCNJ5 mutant APA vs. non-KCNJ5 mutant samples [130].

Regarding adrenocortical carcinoma (ACC), a combined genomic approach classified tumor samples into 3 clusters (Mi1-3) based on miRNA expression pattern [76]. ACC samples in cluster Mi1 showed the largest miRNA expression differences relative to normal adrenal samples. Samples in this Mi cluster were characterized by the downregulation of 38 miRNAs expressed from 14q32 locus and by the upregulation of miRNAs belonging to the Xq27.3 miRNA cluster [76]. By using SNP array and DNA methylation analysis, this study identified $\mathrm{LOH}$ of chromosome arm 14q in all Mi1 ACC tumors associated with $M E G 3$ promoter methylation. The authors suggested that the loss of the maternal unmethylated allele resulted in silencing of the 14q32 miRNA cluster in Mi1 ACC tumors, suggesting that this region had a key role in ACC pathogenesis [76]. Özata and his colleagues, however, found 5 miRNAs from 14q32 (miR-136, miR-127-3p, miR-487b, miR$376 \mathrm{c}$ and miR-432) overexpressed in ACC compared to normal adrenal cortex, but no 14q32 miRNAs were identified in association with survival [75]. Additionally, miR-376a and miR-376b overexpression were also described in ACC vs. ACA samples [54]. Interestingly, while miR-376a was detected as downregulated miRNA, miR-299-5p and miR-485-5p were found overexpressed in ACC vs. hormonally nonfunctioning adenoma, cortisol-producing adenoma and normal adrenal cortex [74].

Regarding ACC behavior miR-370, miR-376a, miR-376b, miR-376c, miR-377, miR-379, miR-382, miR-411, miR-487a, miR-494, and miR-495 encoded at 14q32 miRNA cluster were downregulated in non-aggressive ACC as compared to aggressive ones [54]. In another study, miRNA-665 was overexpressed in ACC as compared to benign adrenocortical tumors [131]. MiR-431 was also reported to be underexpressed in patients with ACC with progressive disease undergoing adjuvant therapy (mitotane, chemotherapy, and radiotherapy) compared to therapy responders [132]. Restoration of miR-431 increased cell responses to adjuvant therapy and led to cell cycle arrest at $S$ phase. Authors demonstrated that Zinc Finger E-Box Binding Homeobox 1 (ZEB1), a target of miR-431, was implicated in reversal of the epithelial-mesenchymal transition (EMT), leading to increased cell responses to adjuvant therapies in ACC [132].

Interestingly, $D L K 1$ was found as a marker of adrenal gland tumor, which was in line with findings that 14q32 miRNAs (except for Mi1 subgroup) were upregulated in ACC suggesting a common transcriptional regulation of the entire locus in ACC (Figure 1) [133]. 


\subsection{Pituitary Neuroendocrine Tumors (PitNET)}

Pituitary adenomas are among the most frequent intracranial tumors with a high incidence rate of approximately 10-15\% [134]. Although the great majority of them are benign, they represent significant morbidity by mass effect or by hormonal disturbance. Generally, pituitary adenomas are sporadic; only $5 \%$ of them occur as part of genetic syndromes such as MEN1, MEN4, Carney complex or McCune-Albright syndrome. Interestingly, miRNAs has been extensively investigated in pituitary tumors, including not only expressional reports, but functional studies [6]. As more than one hundred original publications have reported, findings have been extensively summarized by excellent reviews $[6,135,136]$. Here, authors aimed to only highlight the role of $14 \mathrm{q} 32$ miRNAs in pituitary adenomas using high-throughput studies comparing pituitary adenoma samples to normal pituitary tissues.

Prolactinomas. In a work using next generation sequencing, no $14 \mathrm{q} 32$ miRNAs were reported differentially expressed in prolactinomas [82]. However, with a targeted approach, Cheunsuchon et al. found 7 of 18 investigated 14q32 miRNAs in prolactin (PRL)secreting tumors significantly down-regulated [81]. In line with these results, D'Angelo et al. detected downregulated miR-432 in PRL adenoma tissues and using functional in-vitro assays, high-mobility group AT-hook 2 mRNA (HMGA2) proved to be a miR-432 target [78]. On the contrary, Chen et al. detected miR-432 and miR-493 upregulation compared to normal anterior pituitary gland samples; moreover, they reported a significant positive correlation between the expression of the two miRNAs and the serum level of prolactin [87]. Additionally, of the 14q32 miRNA cluster, miR-410 was found to be upregulated in prolactinomas [86], as well as in 6 out of the 12 GH-secreting adenomas. This finding suggested that a reduced miR-410 expression seemed to be restricted to gonadotroph adenomas.

Growth hormone $(\mathrm{GH})$ producing tumors. Numerous underexpressed miRNA located at $14 q 32$ were identified using NGS and PCR array [80,82] (Figure 1). However, this was not entirely supported by other studies [77,78,81]. While some reported overexpression of miR136 in GH-producing adenomas based on microarray profiling [77], a recent study using NGS and Bottoni et al. reported its downregulation compared to normal pituitary $[79,82]$. Nevertheless, miR-411-3p was overexpressed and miR-381 with miR-654-3p were downregulated from 14q32 locus [77,82]. MiR-370-3p was detected to be underexpressed in pituitary adenomas compared to normal pituitary and in non-functional pituitary adenomas (NFPA) compared to functional ones [137]. Furthermore, its level showed correlation with GH expression determined by immunohistochemistry [137]. Palumbo et al. identified 17 miRNAs to be differentially expressed in GH-producing pituitary tumors; however, none were encoded at 14q32 [138]. Pituitary tumor-transforming 1 (PTTG1) was identified as a target of miR-126 and miR-381 encoded at 14q32 cluster [139]. Also, Liang et al. demonstrated that overexpression of $414 \mathrm{q} 32$ miRNAs (miR-655, miR-300, miR-381 and miR-329) inhibited proliferation, migration and invasion, but induced apoptosis in GH3 and MMQ rat pituitary cells and regulated the PTTG1 expression [90]. The authors suggested a negative feedback loop between PTTG1 targeting miRNAs, PTTG1 and p53 where p53 transcriptionally activated the expression of the four miRNAs, while PTTG1 inhibited the transcriptional activity of p53 [90]. Among 14q32 miRNAs the downregulated miR-432 inhibited cell proliferation of GH3 cells and has a negative role on the growth regulation of pituitary adenoma by targeting HMGA2 [78].

Non-functioning pituitary adenomas (NFPA). Several miRNAs mapped to $14 \mathrm{q} 32$ showed significant underexpression compared to normal pituitary in NFPA detected by different platforms $[86,88,89]$. Besides 32 downregulated miRNAs, MEG3 and DLK1 also showed underexpression in NFPA samples [89]. Indeed, another study investigating the silencing of the imprinted DLK1-MEG3 locus in human NFPAs [81] also reported numerous 14q32 encoded miRNAs expression as lost or significantly diminished compared to normal pituitary. Furthermore, the authors identified these miRNA expression alterations together with increased methylation of MEG3-IG DMR [81,140,141]. This was in line with the finding that MEG3 was not expressed in NFPAs; therefore the authors suggested that 
the silencing of the DLK1-MEG3 locus played an important role in human NFPA pathogenesis [81,140,141]. Among 14q32 miRNAs miR-1185-1-3p was identified upregulated, while miR-493 downregulated [82]. Bottoni et al. found that miR-154, miR-127 and miR-134 were downregulated in NFPA and were predictive miRNAs for the histotype [79]. Others identified downregulation of miR-432 encoded at $14 \mathrm{q} 32$ in NFPA and gonadotroph adenomas [90]. The functional role of miR-432 was investigated in HP75 human pituitary adenoma cells, and miRNA transfection led to a significant reduction of cell number compared to controls [78]. Regarding gonadotroph adenomas reduced miR-410 expression seemed to be restricted to gonadotroph adenomas compared to other adenoma types [86]. Authors validated cyclin B1 (CCNB1) as target of miRNA-410 since its overexpression reduced CCNB1 at protein and mRNA levels, decreasing cell proliferation.

Corticotroph adenomas. Cheunsuchon et al. investigated 18 members of the $14 \mathrm{q} 32$ miRNA cluster, among which several miRNAs identified as significantly downregulated (miR-127-3p, miR-136, miR-154, miR-299-5p, miR-329, miR-369-3p, miR-369-5p, miR-376c, miR-377 and miR-433) and only miR-431 was found overexpressed in tumors compared to normal tissues [81]. Although more than a few downregulated miRNAs were detected in adrenocorticotropin (ACTH)-secreting tumors, their expression levels were considered significantly higher compared to those found in NFPAs [81]. Accordingly, DLK1 was found downregulated in corticotroph tumors [81]. While Stilling et al. detected 5 other miRNAs significantly downregulated located at $14 \mathrm{q} 32$ (miR-323-5p, miR-136*, miR-411*, miR-431*, miR-493) in corticotroph adenomas [85], others failed to detect any differentially expressed miRNAs from 14q32 region [84].

Pituitary carcinomas. In corticotroph carcinomas, miR-323-5p was downregulated in comparison to normal pituitary, and miR-493 was upregulated in carcinoma vs. adenoma [85]. It was suggested that miRNA-493 interacted with galectin-3 (LGALS3, lectin, galactoside-binding, soluble, 3) and Runt-related transcription factor 2 (RUNX2) genes, [142-145]. These data also showed that galectin-3 had a role in regulating cell proliferation and apoptosis of pituitary cells.

Pituitary oncocytoma. In pituitary oncocytoma, numerous underexpressed miRNAs ( $40 \%$ of all downregulated miRNAs) compared to normal control were mapped to $14 \mathrm{q} 32$ region [91].

\subsection{Thyroid Carcinoma}

Thyroid cancer is the most frequent malignant endocrine tumor. The majority of them $(\sim 95 \%)$ arise from follicular cells and classified as papillary (PTC, 75-80\%), follicular (FTC, 10-15\%) or anaplastic thyroid cancer (ATC, 0.2-2\%) [146]. Tumors developing from calcitonin secreting parafollicular $\mathrm{C}$ cells are a distinct entity, and called medullary thyroid cancer (MTC) representing 5-10\% of all thyroid cancers [146]. This subtype commonly occur sporadically; however, approximately $10-25 \%$ of them are hereditary and appear as part of MEN2 syndrome, caused by germline mutations of the RET proto-oncogene [146]. Most of the well differentiated thyroid cancer (including PTC, FTC) has excellent prognosis; however, patients with ATC have 6-12 months median survival [147].

Nikiforova et al. detected markedly different profiles of miRNA expression between MTC and all other thyroid tumors that derives from follicular cells, reflecting tissue-specific characteristics of miRNAs [94]. Among these, several 14q32 miRNAs were overexpressed in MTC compared to normal and other thyroid cancer types [94]. Expectedly, Lassalle et al. detected numerous miRNAs differentially expressed between sporadic and hereditary MTC cases including miR-136, miR-487b, miR-376a,c, and miR-127 located at 14q32 miRNA cluster [92]. Interestingly, the highly expressed miR-375 was revealed as a novel circulating prognostic marker for MTC patients as well, as MTC patients had significantly higher miR-375 plasma levels than healthy controls and subjects in remission [148]. Additionally, high circulating miR-375 level was associated with significantly reduced overall survival and was a strong prognostic factor of poor prognosis [148]. 
Numerous miRNAs were described in non-medullary thyroid cancer types, however, with controversial results. Therefore, a comprehensive re-analysis integrating 21 thyroid cancer miRNA studies by Saiselet et al. determined the commonly reported differentially expressed miRNAs in non-medullary thyroid carcinomas compared to normal tissues [149]. Of the investigated studies, in FTC and ATC, no differentially expressed miRNA encoded at 14q32 miRNAs occurred except the downregulated miR-299 in FTC $[149,150]$. However, 4 overexpressed (miR-134, miR-136, miR-409, miR-654) and several underexpressed (miR124, miR-134, miR-300, miR-379, miR-382 and miR-494-3p, miR-494-5p and miR-495) 14q32 miRNA were identified in PTC samples. In a more recent study, the global downregulation of miRNAs from the 14q32 region in human PTC was also confirmed [95]. The decreased miR-654-3p levels with long-term PTC progression in Tg-Braf mice was also observed and the level of miR-654-3p inversely correlated with epithelial-mesenchymal transition (EMT) [95]. The in-vitro restoration of miR-654-3p inhibited cell proliferation and migration and induced reprogramming of metastasis-related genes, supporting the tumor suppressor role for this miRNA [95]. Interestingly, in another study analyzing miRNA expression profiles in classical-type PTC, follicular-variant PTC, and tall-cell variant, no 14q32 miRNA was detected compared normal adjacent thyroid tissues [96].

From a clinical point of view miRNAs are suggested as potential biomarkers, as cytology following fine-needle aspiration biopsy (FNAB) are interpreted as indeterminate without definitive diagnosis regarding thyroid tumors in 3-6\% to 10-25\% [147]. However, miRNAs located at $14 \mathrm{q} 32$ did not help in discriminating benign vs. malignant thyroid lesions from FNAB samples [6].

\section{Different Expression of 14q32 miRNA Cluster Members}

$14 q 32$ locus contains more than forty miRNAs, and previously it had been thought that they were generated from one polycistronic transcript containing the whole miRNA cluster under a coordinated regulation with the MEG3 non-coding RNA located upstream $[7,12,151]$. Also, hyper-methylation of the 14q32 DMRs was described to associate with decreased 14q32 miRNA expression and vice versa, suggesting that the entire imprinted cluster is regulated jointly $[37,44,45,152]$.

However, in several endocrine tumors, the pattern of $14 \mathrm{q} 32$ miRNAs were not so homogenous. Indeed, in other tissues and tumor types, similar findings were described $[10,153,154]$. Also, in non-tumorous cells not all of the members of $14 q 32$ miRNA cluster were expressed in all tissues and 14q32 miRNAs demonstrated varying level of expression, suggesting other possible regulating mechanisms [155]. Indeed, the expression of protein-coding and non-coding genes encoded at the $14 \mathrm{q} 32$ locus was regulated by epigenetic changes, but the exact mechanism behind controlling this process is not entirely known $[21,36,46,68,156,157]$.

However, several mechanisms have been identified in the context of this variable expression of the cluster members, among which methylation was the most obvious. Genomic imprinting imbalance could result in the differential modulation of paternally and maternally expressed genes from the $14 \mathrm{q} 32$ region that might serve as an explanation, at least in part, for the increased levels of DIO3 observed in some papillary thyroid cancer samples $[95,153,158]$. Various DNA methylation patterns of the $14 q 32$ locus were observed in different blood vessel types, which were not associated with miRNA expression [10]. Direct correlation was not possible to be proven between 14q32 estimated methylation fraction of multiple cytosines followed by guanine residues $(\mathrm{CpG})$ in the 3 DMRs located along 14q32 and 14q32 miRNA expression [10]. Moreover, neither DNMT gene expression or DNA methylation did not correlate with primary or mature miRNA expression [10]. In urothelial carcinoma, distinctive epigenetic alterations were again observed at the three regions controlling DLK1 and MEG3 expression [154]. The authors suggested that altered nucleosomal positioning could account for the irregular patterning of DNA methylation; namely, that one specific CpG site became significantly hypomethylated in cancer cells, while methylation of flanking sites rather increased [154]. 
Recent studies have shown that chromatin remodeling by lncRNA-mediated mechanisms, may also participate in regulating the expression of the 14q32-encoded miRNAs [46,68].

Additionally, Greife and colleagues demonstrated the loss of active and gain of repressive histone modifications at all regulatory sequences using chromatin immunoprecipitation [154].

Differences in miRNA splicing, primary transcript processing or pre-miRNA cleavage and maturation were also reported related to $14 \mathrm{q} 32$ miRNAs [159]. Some suggested that the expression of miRNA clustered on $14 \mathrm{q} 32$ might be particularly sensitive to changes in the miRNA biogenesis pathway [159-161]. A large proportion of 14q32 encoded miRNAs contained structural features associated with Dicer-independent processing [162], therefore Ago2-dependent pre-miRNA processing $[162,163]$ was particularly important for the biogenesis of miRNA in this cluster. Goossens et al. reinforced that miRNA-specific expression fingerprints implied individual regulation of 14q32 miRNA expression [10].

RNA Binding Proteins (RBPs) were other post-transcriptional regulators of miRNA expression. RBPs bound precursor miRNAs and promoted or inhibited their maturation. For instance, Myocyte Enhancer Factor 2A (MEF2A) was such an RBP regulating miR329 and miR-494 encoded at 14q32 chromosomal region [164]. Cold-inducible RNAbinding protein $(C I R B P)$ and hydroxyacyl-CoA dehydrogenase trifunctional multienzyme complex subunit $\beta(H A D H B)$ were also RNA binding proteins that regulated 14q32 miRNA expression [165].

The different expressional pattern regarding this miRNA cluster was also observed by Manodoro et al., who attributed it to the presence of the binding sites of CCCTCbinding factor (CTCF) which was implicated in transcriptional activation/repression and imprinting $[32,157,166]$. CTCF exerted its regulatory function by binding to unmethylated DNA in an allele-specific manner $[167,168]$. Interestingly, it was found that different CTCF binding sites display a different influence on 14q32 miRNA expression depending on the position [157].

Altogether, these data suggest that multiple mechanisms other than genetic mutations or chromosomal loss might be involved in the regulation of 14q32-encoded miRNAs.

\section{Functional Impact of $14 q 32$ miRNAs}

By analyzing function of individual 14q32 miRNAs, besides several molecular functions and biological processes, TGF $\beta$ and Wnt signaling were also identified, which are frequently involved in tumor development (Supplementary Table S1).

However, as 14q32 miRNAs more or less function in cooperation, we performed target prediction and gene set enrichment analysis to investigate the net effect of their co-expressional pattern. Several cancer-related pathways (including TGF- $\beta$ signaling, Ras signaling, ErbB signaling), pathways involved in invasiveness and metastasis development (e.g., proteoglycans in cancer, adherens junction) or influencing pluripotency and stemness were identified as a potentially functional role (Table 3).

Literature/experimental data also suggested the regulation of axon guidance, actin cytoskeleton, focal adhesion, mammalian target of rapamycin, calcium, mitogen-activated protein kinase and ErbB signaling pathways by 14q32 miRNAs [159]. Liu et al. found that these miRNAs were highly associated with cellular pluripotency [35]. Interestingly, the transcription factor, $M E F 2 A$ regulated the expression of $14 \mathrm{q} 32$ miRNAs being a direct target of miR-329 [169]. Uppal and colleagues, using mRNA profiling and bioinformatics, demonstrated that $14 \mathrm{q} 32$ miRNAs target genes in PI3K/AKT/mTOR and TGF- $\beta$ pathways were involved in focal adhesion, cell-extracellular matrix interactions, gap junctions and actin cytoskeleton, resulting in impaired adhesion, invasion and migration, processes that were essential for the development of metastases [22,170,171]. The regulation of $\mathrm{PI}$ KK/AKT/mTOR and TGF- $\beta$ pathways by $14 \mathrm{q} 32$ miRNAs was also strengthened by Qian and colleagues in hemopoietic stem cells as well [172]. 
Table 3. Top 20 significant signaling pathway regulated by $14 \mathrm{q} 32$ miRNAs.

\begin{tabular}{cccc}
\hline KEGG Pathway & $p$-Value & \# Genes & \# miRNAs \\
\hline Hippo signaling pathway (hsa04390) & $2.635 \times 10^{-7}$ & 103 & 47 \\
Proteoglycans in cancer (hsa05205) & $2.507 \times 10^{-6}$ & 132 & 48 \\
Pathways in cancer (hsa05200) & $3.424 \times 10^{-6}$ & 255 & 48 \\
Adherens junction (hsa04520) & $1.345 \times 10^{-5}$ & 57 & 41 \\
TGF- $\beta$ signaling pathway (hsa04350) & $1.582 \times 10^{-5}$ & 58 & 45 \\
Axon guidance (hsa04360) & $2.465 \times 10^{-5}$ & 88 & 45 \\
Rap1 signaling pathway (hsa04015) & $3.946 \times 10^{-5}$ & 141 & 48 \\
Glioma (hsa05214) & $4.825 \times 10^{-5}$ & 47 & 43 \\
Ras signaling pathway (hsa04014) & $4.825 \times 10^{-5}$ & 146 & 49 \\
Circadian rhythm (hsa04710) & $6.429 \times 10^{-5}$ & 27 & 37 \\
Lysine degradation (hsa00310) & $9.643 \times 10^{-5}$ & 33 & 43 \\
Signaling pathways regulating pluripotency & 0.0001 & 96 & 50 \\
of stem cells (hsa04550) & 0.0001 & 92 & 46 \\
FoxO signaling pathway (hsa04068) & 0.0001 & 79 & 46 \\
Thyroid hormone signaling & 0.0004 & 93 & 44 \\
pathway (hsa04919) & 0.0006 & 24 & 36 \\
Ubiquitin mediated proteolysis (hsa04120) & 0.0009 & 17 & 26 \\
Dorso-ventral axis formation (hsa04320) & 0.0011 & 63 & 45 \\
Prion diseases (hsa05020) & 0.0015 & 48 & 41 \\
ErbB signaling pathway (hsa04012) & 0.0023 & 48 & 43 \\
Renal cell carcinoma (hsa05211) & & & \\
Pancreatic cancer (hsa05212) & & & \\
\hline
\end{tabular}

In osteosarcoma, the decrease of 14q32 miRNA levels stabilized c-MYC protooncogene expression and consequently increased the level of oncogenic miR-17-92 miRNA cluster [173]. Cell cycle and epithelial-mesenchymal transition (EMT) were also proved to be influenced by $14 q 32$ miRNAs $[38,47,95,174]$. Genes involved in metastasis development were also enriched among 14q32 miRNA targets [47]. Cyclin dependent kinase 5 (CDK5) and Twist Family BHLH Transcription Factor 1 (TWIST1) have been reported to increase metastasis through regulating cell cycle and EMT and they were found to be upregulated in osteosarcoma tumors with low levels of 14q32 miRNAs [47,174,175]. Furthermore, thymidine kinase 1 (TK1), that expressed at high levels in proliferating cells and appeared to correlate with high risk in multiple cancer types, was negatively correlated with $14 \mathrm{q} 32$ miRNA expression [47,176-178].

In thyroid cancer, the role of $14 \mathrm{q} 32$ miRNAs was particularly investigated. Geraldo et al. showed that $14 \mathrm{q} 32$ miRNAs contributed to tumor progression and metastasis by targeting key regulators of cell adhesion, migration, proliferation, hypoxic response and wound healing [95]. The reintroduction of miR-654-3p reversed EMT by targeting, hence increasing the expression of cadherin 1 (CDH1) and catenin $\alpha 1$ (CTNNA1), and decreasing the expression of Snail Family Transcriptional Repressor 2 (SNAI2) [95]. Also, it was demonstrated that genes involved in tumor progression (ECM-remodeling and metastasis) were restored after transfection of a miR-654-3p mimetic [95].

Angiogenesis and neovascularization were also significantly regulated by $14 \mathrm{q} 32 \mathrm{miR}-$ NAs. This was confirmed by identifying vascular endothelial growth factor A (VEGFA) as a target of miR-494 [169], as well as of miR-127 [179]. Furthermore, miR-495 were demonstrated to target $\mathrm{C}-\mathrm{C}$ motif chemokine ligand 2 (CCL2), through which it affects proliferation and apoptosis of human umbilical vein endothelial cells (HUVECs) [180]. Forkhead box O1 (FOXO1) influencing endothelial growth and proliferation [181], wound closure and vascular density was also identified as a target molecule of miR-544 in colorectal cancer [181-183]. The role of $414 \mathrm{q} 32 \mathrm{miRNAs}$ was additionally proved in in vivo experiments, as the inhibition of miR-329, miR-494, miR-487b and miR-495 in mice stimulated neovascularization after hind limb ischemia $[10,169]$. 


\section{Summary and Discussion}

Altogether, $14 \mathrm{q} 32$ miRNAs have an important role in development and tumorigenesis. The importance of this miRNA cluster regulatory function is represented by the finding that their expression is stable in healthy cells, and even in cell-free serum samples. Their expression is also independent of the most common confounding factors, such as age, sex or BMI. Several studies have shown downregulation of miRNAs from the 14q32 region in different types of cancer; however, 14q32 miRNAs are overexpressed in some cancer types reflecting the tissue-specificity of miRNA function.

Among different endocrine tumors in pituitary adenoma and oncocytoma, papillary thyroid cancer and a particular subset of pheochromocytoma and adrenocortical cancer are characterized by the downregulation of almost all miRNAs encoded by the 14q32 cluster. In the subgroups of ACC and PCC, the silencing of the imprinted $14 \mathrm{q} 32$ cluster due to LOH of chromosome arm 14q or 14q32 locus. In other tumor types including NFPA and/or gonadotroph pituitary adenomas increased methylation of the region DMRs could explain the orchestrated downregulation of the coding and non-coding gene expression of the entire region.

Interestingly, pancreas NET, most of the adrenocortical cancer cases and medullary thyroid cancer are particularly distinct, as $14 \mathrm{q} 32$ miRNAs are overexpressed in these tumors. The role of these overexpressed miRNAs should be further investigated in relation to tumorigenesis.

In the third group of endocrine tumor types such as pheochromocytoma and growthhormone producing tumors, and based on the expression pattern of $14 \mathrm{q} 32$ miRNAs, however, both increased and decreased expression of 14q32 miRNAs cluster members were observed. In the background of this phenomenon, methodological, technical and biological factors can be hypothesized as well. Different researcher groups applied different study design, different sample numbers, RNA extraction and miRNA quantification methods which all could lead to controversial results. Also, as detailed above, several biological explanations have been revealed in the context of the various expressional pattern of the different members of 14q32 miRNA clusters; e.g., different methylation pattern, chromatin remodeling, histone modifications, alteration of miRNA biogenesis, the effects of RNA binding proteins and transcription factors. These factors await being further investigated in pheochromocytoma and growth-hormone producing pituitary adenomas.

Unfortunately, the function of 14q32 in endocrine tumors is not so broadly investigated compared to other tumor types. However, in different types of pituitary adenoma cell lines, $14 \mathrm{q} 32 \mathrm{miRNAs}$ proved their tumor suppressor role by inducing cell cycle arrest and cell growth inhibition by targeting PTTG1 and HMGA2. In PTC, the significance of another 14q32 miRNA, miR-654-3p, was demonstrated in in vivo experiments as it influenced proliferation, migration, metastasis-related gene expression and EMT.

$14 \mathrm{q} 32$ miRNAs are also associated with disease prognosis. In endocrine tumors several $14 \mathrm{q} 32$ miRNAs were identified as prognostic markers in pancreatic, small intestinal and lung NET. Some of these miRNAs are also linked to patient survival in lung NET. In PCC $14 \mathrm{q} 32$ miRNAs indicated metastatic cases compared to non-metastatic cases, assisting the discrimination of benign and malignant tumors. Also, the higher expression of miRNAs encoded at 14q32 were associated with aggressive ACC cases. Finally, while in MTC, 14q32 miRNA miR-375 has not only been reported as a strong prognostic factor of poor prognosis, but its higher level was associated with reduced overall survival, while on the contrary, the decreased 14q32 miRNA in PTC was associated with long-term progression.

Based on data presented in Figure 1, we found some miRNAs unique among endocrine tumor types (miR-337 and miR-758 overexpression in pNET, miR-329 and miR-541 overexpression in PCC/PGL and miR-376c overexpression in MTC). However, there is no full consensus among miRNA profiling studies; i.e., not all studies identified the same miRNAs differentially expressed, and therefore these findings should be further validated. The discrepancy can be due to different study design, difference in sample number (statistical power) and also due to technical factors (e.g., different platforms for high-throughput 
profiling). Analyzing expressional pattern of 14q32 miRNA cluster instead of individual miRNAs, characteristic/unique expression profile was described in MTC compared to other thyroid carcinoma type [94] or in different types of pituitary adenoma [79,81]. Furthermore, even the same type of endocrine tumor, pheochromocytoma can be grouped by different miRNA pattern according to germline mutational background [71]. As 14q32 miRNAs were found to be dysregulated in several cancer types, globally, they cannot be considered as unique tissue biomarkers. Another level of use can be their application in liquid biopsy samples e.g., in circulation. This is supported by the finding that $14 \mathrm{q} 32$ miRNAs were stable in serum and their level was not significantly affected by common confounder factors [11]. Already, the potential use of circulating miRNAs has been suggested in endocrine tumors. In ACC a unique, tissue specific miRNA, miR-483-5p has been suggested as a potential candidate as predictive marker for recurrence [54], and miR-146a-5p and miR-221-3p as serum biomarkers for post-treatment monitoring of PTC patients [96]. Unfortunately, to our best knowledge, no 14q32 mapped miRNA in circulation has been investigated in endocrine tumors. However, in non-endocrine tumor types their expression indicate prognosis and survival [155]. Accordingly, this miRNA cluster was proved to influence EMT process and metastasis development [95,132], hence, they may be used as prognostic biomarker in endocrine tumors as well.

The evolutional role and constraint can be considered another point of view of imprinted miRNAs [184-186]. It was suggested that imprinted noncoding RNAs was under distinctive selective forces when regulating transcripts of the allele inherited from the other parent [184-187]. Accordingly, when an mRNA had sequence complementary to an imprinted miRNA, the complementary miRNA-mRNA sequences pair originated from different alleles. This can be considered a communication between the maternal and paternal alleles, hence the two alleles coordinate their activities [186]. The kinship theory considers genomic imprinting as a mechanism to change gene dosage, because it has a differential effect on the fitness of matrilineal and patrilineal relatives [184-187]. Additionally, Haig and Mainieri suggested that when an imprinted miRNA targets an unimprinted mRNA, their interaction may have different fitness consequences for the loci encoding the miRNA and mRNA [184]. In a recent study, HMGA2 was proposed as an attractive candidate to be one of the original targets because its $3^{\prime}$ regulatory region contained multiple predicted target sites for $14 \mathrm{q} 32$ miRNAs, with some of these target sites evolutionarily older than the 14q32 miRNA cluster [184]. HMGA2 have special role in this context as it has reported to be overexpressed in several cancer type including endocrine tumors and often regulated by miRNAs [188,189], which also highlights the role of $14 q 32$ miRNAs in tumorigenesis.

\section{Conclusions}

Similar to other cancer types, 14q32 miRNAs have a significant role in the tumorigenesis of endocrine glands. In different endocrine tumor types this miRNA cluster reflects the general tissue specificity of miRNAs regarding expression pattern, tumor suppressor or oncogene function, and they have a significant impact on prognosis as well. Regarding the stable expression of $14 \mathrm{q} 32 \mathrm{miRNAs}$ in healthy individuals in circulation, the further investigation of this miRNA cluster could provide an option to use them as diagnostic or prognostic biomarkers in endocrine neoplasms.

Supplementary Materials: The following are available online at https:/ /www.mdpi.com/article/ 10.3390/genes12050698/s1, Table S1: 14q32 miRNAs and their function.

Author Contributions: Conceptualization, H.B. and A.P.; literature mining, H.B. and L.K.; bioinformatics analysis, H.B. and L.K.; data curation, H.B.; writing—original draft preparation, H.B.; writing-review and editing, A.P.; visualization, L.K.; supervision, A.P.; funding acquisition, H.B. All authors have read and agreed to the published version of the manuscript.

Funding: The research was supported by a Hungarian Scientific Research Grant of the National Research, Development and Innovation Office (NKFI FK 135065) to Henriett Butz.

Institutional Review Board Statement: Not applicable. 
Informed Consent Statement: Not applicable.

Data Availability Statement: All relevant data are included in the manuscript.

Conflicts of Interest: The authors declare no conflict of interest.

\section{References}

1. Yates, L.A.; Norbury, C.J.; Gilbert, R.J.C. The Long and Short of MicroRNA. Cell 2013, 153, 516-519. [CrossRef]

2. Valinezhad Orang, A.; Safaralizadeh, R.; Kazemzadeh-Bavili, M. Mechanisms of MiRNA-Mediated Gene Regulation from Common Downregulation to MRNA-Specific Upregulation. Int. J. Genom. 2014, 2014, 970607. [CrossRef]

3. Lewis, B.P.; Burge, C.B.; Bartel, D.P. Conserved Seed Pairing, Often Flanked by Adenosines, Indicates That Thousands of Human Genes Are MicroRNA Targets. Cell 2005, 120, 15-20. [CrossRef] [PubMed]

4. Mattick, J.S.; Makunin, I.V. Small Regulatory RNAs in Mammals. Hum. Mol. Genet. 2005, 14 (Suppl. S1), R121-R132. [CrossRef] [PubMed]

5. Peng, C.; Wang, Y.-L. Editorial: MicroRNAs as New Players in Endocrinology. Front. Endocrinol. 2018, 9, 459. [CrossRef] [PubMed]

6. Butz, H.; Patócs, A. MicroRNAs in Endocrine Tumors. EJIFCC 2019, 30, 146-164. [PubMed]

7. Seitz, H. A Large Imprinted MicroRNA Gene Cluster at the Mouse Dlk1-Gtl2 Domain. Genome Res. 2004, 14, 1741-1748. [CrossRef]

8. Cavaillé, J.; Seitz, H.; Paulsen, M.; Ferguson-Smith, A.C.; Bachellerie, J.-P. Identification of Tandemly-Repeated C/D SnoRNA Genes at the Imprinted Human 14q32 Domain Reminiscent of Those at the Prader-Willi/Angelman Syndrome Region. Hum. Mol. Genet. 2002, 11, 1527-1538. [CrossRef]

9. Royo, H.; Cavaillé, J. Non-Coding RNAs in Imprinted Gene Clusters. Biol. Cell 2008, 100, 149-166. [CrossRef]

10. Goossens, E.A.C.; de Vries, M.R.; Simons, K.H.; Putter, H.; Quax, P.H.A.; Nossent, A.Y. MiRMap: Profiling 14q32 MicroRNA Expression and DNA Methylation throughout the Human Vasculature. Front. Cardiovasc. Med. 2019, 6. [CrossRef]

11. Valbuena, G.N.; Apostolidou, S.; Roberts, R.; Barnes, J.; Alderton, W.; Harper, L.; Jacobs, I.; Menon, U.; Keun, H.C. The 14q32 Maternally Imprinted Locus Is a Major Source of Longitudinally Stable Circulating MicroRNAs as Measured by Small RNA Sequencing. Sci. Rep. 2019, 9, 15787. [CrossRef]

12. Glazov, E.A.; McWilliam, S.; Barris, W.C.; Dalrymple, B.P. Origin, Evolution, and Biological Role of MiRNA Cluster in DLK-DIO3 Genomic Region in Placental Mammals. Mol. Biol. Evol. 2008, 25, 939-948. [CrossRef] [PubMed]

13. Benetatos, L.; Voulgaris, E.; Vartholomatos, G. DLK1-MEG3 Imprinted Domain MicroRNAs in Cancer Biology. Crit. Rev. Eukaryot. Gene Expr. 2012, 22, 1-15. [CrossRef]

14. Benetatos, L.; Vartholomatos, G.; Hatzimichael, E. MEG3 Imprinted Gene Contribution in Tumorigenesis. Int. J. Cancer 2011, 129, 773-779. [CrossRef] [PubMed]

15. Wienholds, E. MicroRNA Expression in Zebrafish Embryonic Development. Science 2005, 309, 310-311. [CrossRef] [PubMed]

16. Swarbrick, A.; Woods, S.L.; Shaw, A.; Balakrishnan, A.; Phua, Y.; Nguyen, A.; Chanthery, Y.; Lim, L.; Ashton, L.J.; Judson, R.L.; et al. MiR-380-5p Represses P53 to Control Cellular Survival and Is Associated with Poor Outcome in MYCN Amplified Neuroblastoma. Nat. Med. 2010, 16, 1134-1140. [CrossRef]

17. Holder, J.L.; Lotze, T.E.; Bacino, C.; Cheung, S.-W. A Child with an Inherited $0.31 \mathrm{Mb}$ Microdeletion of Chromosome 14q32.33: Further Delineation of a Critical Region for the 14q32 Deletion Syndrome. Am. J. Med. Genet. A 2012, 158A, 1962-1966. [CrossRef]

18. Briggs, T.A.; Lokulo-Sodipe, K.; Chandler, K.E.; Mackay, D.J.G.; Temple, I.K. Temple Syndrome as a Result of Isolated Hypomethylation of the 14q32 Imprinted DLK1/MEG3 Region. Am. J. Med. Genet. A 2016, 170A, 170-175. [CrossRef]

19. Bens, S.; Kolarova, J.; Gillessen-Kaesbach, G.; Buiting, K.; Beygo, J.; Caliebe, A.; Ammerpohl, O.; Siebert, R. The Differentially Methylated Region of MEG8 Is Hypermethylated in Patients with Temple Syndrome. Epigenomics 2015, 7, 1089-1097. [CrossRef]

20. Kagami, M.; O'Sullivan, M.J.; Green, A.J.; Watabe, Y.; Arisaka, O.; Masawa, N.; Matsuoka, K.; Fukami, M.; Matsubara, K.; Kato, F.; et al. The IG-DMR and the MEG3-DMR at Human Chromosome 14q32.2: Hierarchical Interaction and Distinct Functional Properties as Imprinting Control Centers. PLoS Genet. 2010, 6, e1000992. [CrossRef] [PubMed]

21. Kagami, M.; Sekita, Y.; Nishimura, G.; Irie, M.; Kato, F.; Okada, M.; Yamamori, S.; Kishimoto, H.; Nakayama, M.; Tanaka, Y.; et al. Deletions and Epimutations Affecting the Human 14q32.2 Imprinted Region in Individuals with Paternal and Maternal Upd(14)like Phenotypes. Nat. Genet. 2008, 40, 237-242. [CrossRef]

22. Uppal, A.; Wightman, S.C.; Mallon, S.; Oshima, G.; Pitroda, S.P.; Zhang, Q.; Huang, X.; Darga, T.E.; Huang, L.; Andrade, J.; et al. 14q32-Encoded MicroRNAs Mediate an Oligometastatic Phenotype. Oncotarget 2015, 6, 3540-3552. [CrossRef]

23. Rosenfeld, J.A.; Fox, J.E.; Descartes, M.; Brewer, F.; Stroud, T.; Gorski, J.L.; Upton, S.J.; Moeschler, J.B.; Monteleone, B.; Neill, N.J.; et al. Clinical Features Associated with Copy Number Variations of the 14q32 Imprinted Gene Cluster. Am. J. Med. Genet. Part A 2015, 167, 345-353. [CrossRef] [PubMed]

24. Ogata, T.; Kagami, M. Kagami-Ogata Syndrome: A Clinically Recognizable Upd(14)Pat and Related Disorder Affecting the Chromosome 14q32.2 Imprinted Region. J. Hum. Genet. 2016, 61, 87-94. [CrossRef]

25. Sun, M.; Xia, R.; Jin, F.; Xu, T.; Liu, Z.; De, W.; Liu, X. Downregulated Long Noncoding RNA MEG3 Is Associated with Poor Prognosis and Promotes Cell Proliferation in Gastric Cancer. Tumour Biol. 2014, 35, 1065-1073. [CrossRef] [PubMed]

26. Béna, F.; Gimelli, S.; Migliavacca, E.; Brun-Druc, N.; Buiting, K.; Antonarakis, S.E.; Sharp, A.J. A Recurrent 14q32.2 Microdeletion Mediated by Expanded TGG Repeats. Hum. Mol. Genet. 2010, 19, 1967-1973. [CrossRef] [PubMed] 
27. Kawakami, T.; Chano, T.; Minami, K.; Okabe, H.; Okada, Y.; Okamoto, K. Imprinted DLK1 Is a Putative Tumor Suppressor Gene and Inactivated by Epimutation at the Region Upstream of GTL2 in Human Renal Cell Carcinoma. Hum. Mol. Genet. 2006, 15, 821-830. [CrossRef]

28. Sanlaville, D.; Aubry, M.C.; Dumez, Y.; Nolen, M.C.; Amiel, J.; Pinson, M.P.; Lyonnet, S.; Munnich, A.; Vekemans, M.; MorichonDelvallez, N. Maternal Uniparental Heterodisomy of Chromosome 14: Chromosomal Mechanism and Clinical Follow Up. J. Med. Genet. 2000, 37, 525-528. [CrossRef]

29. Temple, I.K.; Shrubb, V.; Lever, M.; Bullman, H.; Mackay, D.J.G. Isolated Imprinting Mutation of the DLK1/GTL2 Locus Associated with a Clinical Presentation of Maternal Uniparental Disomy of Chromosome 14. J. Med. Genet. 2007, 44, 637-640. [CrossRef]

30. Da Rocha, S.T.; Edwards, C.A.; Ito, M.; Ogata, T.; Ferguson-Smith, A.C. Genomic Imprinting at the Mammalian Dlk1-Dio3 Domain. Trends Genet. 2008, 24, 306-316. [CrossRef] [PubMed]

31. Hagan, J.P.; O’Neill, B.L.; Stewart, C.L.; Kozlov, S.V.; Croce, C.M. At Least Ten Genes Define the Imprinted Dlk1-Dio3 Cluster on Mouse Chromosome 12qF1. PLoS ONE 2009, 4, e4352. [CrossRef] [PubMed]

32. Wylie, A.A.; Murphy, S.K.; Orton, T.C.; Jirtle, R.L. Novel Imprinted DLK1/GTL2 Domain on Human Chromosome 14 Contains Motifs That Mimic Those Implicated in IGF2/H19 Regulation. Genome Res. 2000, 10, 1711-1718. [CrossRef] [PubMed]

33. Takada, S.; Paulsen, M.; Tevendale, M.; Tsai, C.-E.; Kelsey, G.; Cattanach, B.M.; Ferguson-Smith, A.C. Epigenetic Analysis of the Dlk1-Gtl2 Imprinted Domain on Mouse Chromosome 12: Implications for Imprinting Control from Comparison with Igf2-H19. Hum. Mol. Genet. 2002, 11, 77-86. [CrossRef] [PubMed]

34. Schmidt, J.V.; Matteson, P.G.; Jones, B.K.; Guan, X.J.; Tilghman, S.M. The Dlk1 and Gt12 Genes Are Linked and Reciprocally Imprinted. Genes Dev. 2000, 14, 1997-2002. [PubMed]

35. Liu, L.; Luo, G.-Z.; Yang, W.; Zhao, X.; Zheng, Q.; Lv, Z.; Li, W.; Wu, H.-J.; Wang, L.; Wang, X.-J.; et al. Activation of the Imprinted Dlk1-Dio3 Region Correlates with Pluripotency Levels of Mouse Stem Cells. J. Biol. Chem. 2010, 285, 19483-19490. [CrossRef] [PubMed]

36. Kameswaran, V.; Bramswig, N.C.; McKenna, L.B.; Penn, M.; Schug, J.; Hand, N.J.; Chen, Y.; Choi, I.; Vourekas, A.; Won, K.-J.; et al. Epigenetic Regulation of the DLK1-MEG3 MicroRNA Cluster in Human Type 2 Diabetic Islets. Cell Metab. 2014, 19, 135-145. [CrossRef] [PubMed]

37. Guo, W.; Dong, Z.; Liu, S.; Qiao, Y.; Kuang, G.; Guo, Y.; Shen, S.; Liang, J. Promoter Hypermethylation-Mediated Downregulation of MiR-770 and Its Host Gene MEG3, a Long Non-Coding RNA, in the Development of Gastric Cardia Adenocarcinoma. Mol. Carcinog. 2017, 56, 1924-1934. [CrossRef]

38. González-Vallinas, M.; Rodríguez-Paredes, M.; Albrecht, M.; Sticht, C.; Stichel, D.; Gutekunst, J.; Pitea, A.; Sass, S.; SánchezRivera, F.J.; Lorenzo-Bermejo, J.; et al. Epigenetically Regulated Chromosome 14q32 MiRNA Cluster Induces Metastasis and Predicts Poor Prognosis in Lung Adenocarcinoma Patients. Mol. Cancer Res. 2018, 16, 390-402. [CrossRef]

39. Moradi, S.; Sharifi-Zarchi, A.; Ahmadi, A.; Mollamohammadi, S.; Stubenvoll, A.; Günther, S.; Salekdeh, G.H.; Asgari, S.; Braun, T.; Baharvand, H. Small RNA Sequencing Reveals Dlk1-Dio3 Locus-Embedded MicroRNAs as Major Drivers of Ground-State Pluripotency. Stem Cell Rep. 2017, 9, 2081-2096. [CrossRef]

40. Xi, S.; Xu, H.; Shan, J.; Tao, Y.; Hong, J.A.; Inchauste, S.; Zhang, M.; Kunst, T.F.; Mercedes, L.; Schrump, D.S. Cigarette Smoke Mediates Epigenetic Repression of MiR-487b during Pulmonary Carcinogenesis. J. Clin. Investig. 2013, 123, 1241-1261. [CrossRef]

41. Oshima, G.; Poli, E.C.; Bolt, M.J.; Chlenski, A.; Forde, M.; Jutzy, J.M.S.; Biyani, N.; Posner, M.C.; Pitroda, S.P.; Weichselbaum, R.R.; et al. DNA Methylation Controls Metastasis-Suppressive 14q32-Encoded MiRNAs. Cancer Res. 2019, 79, 650-662. [CrossRef]

42. Kelly, L.; Bryan, K.; Kim, S.Y.; Janeway, K.A.; Killian, J.K.; Schildhaus, H.-U.; Miettinen, M.; Helman, L.; Meltzer, P.S.; van de Rijn, M.; et al. Post-Transcriptional Dysregulation by MiRNAs Is Implicated in the Pathogenesis of Gastrointestinal Stromal Tumor [GIST]. PLoS ONE 2013, 8, e64102. [CrossRef]

43. Anaya-Ruiz, M.; Bandala, C.; Perez-Santos, J.L.M. MiR-485 Acts as a Tumor Suppressor by Inhibiting Cell Growth and Migration in Breast Carcinoma T47D Cells. Asian Pac. J. Cancer Prev. 2013, 14, 3757-3760. [CrossRef]

44. Qin, R.; Chen, Z.; Ding, Y.; Hao, J.; Hu, J.; Guo, F. Long Non-Coding RNA MEG3 Inhibits the Proliferation of Cervical Carcinoma Cells through the Induction of Cell Cycle Arrest and Apoptosis. Neoplasma 2013, 60, 486-492. [CrossRef]

45. Ying, L.; Huang, Y.; Chen, H.; Wang, Y.; Xia, L.; Chen, Y.; Liu, Y.; Qiu, F. Downregulated MEG3 Activates Autophagy and Increases Cell Proliferation in Bladder Cancer. Mol. Biosyst. 2013, 9, 407-411. [CrossRef]

46. Formosa, A.; Markert, E.K.; Lena, A.M.; Italiano, D.; Finazzi-Agrò, E.; Levine, A.J.; Bernardini, S.; Garabadgiu, A.V.; Melino, G.; Candi, E. MicroRNAs, MiR-154, MiR-299-5p, MiR-376a, MiR-376c, MiR-377, MiR-381, MiR-487b, MiR-485-3p, MiR-495 and MiR-654-3p, Mapped to the 14q32.31 Locus, Regulate Proliferation, Apoptosis, Migration and Invasion in Metastatic Prostate Cancer Cells. Oncogene 2014, 33, 5173-5182. [CrossRef]

47. Sarver, A.L.; Thayanithy, V.; Scott, M.C.; Cleton-Jansen, A.-M.; Hogendoorn, P.C.; Modiano, J.F.; Subramanian, S. MicroRNAs at the Human 14q32 Locus Have Prognostic Significance in Osteosarcoma. Orphanet J. Rare Dis. 2013, 8, 7. [CrossRef] [PubMed]

48. Zehavi, L.; Avraham, R.; Barzilai, A.; Bar-Ilan, D.; Navon, R.; Sidi, Y.; Avni, D.; Leibowitz-Amit, R. Silencing of a Large MicroRNA Cluster on Human Chromosome 14q32 in Melanoma: Biological Effects of Mir-376a and Mir-376c on Insulin Growth Factor 1 Receptor. Mol. Cancer 2012, 11, 44. [CrossRef] [PubMed]

49. Niu, C.S.; Yang, Y.; Cheng, C.-D. MiR-134 Regulates the Proliferation and Invasion of Glioblastoma Cells by Reducing Nanog Expression. Int. J. Oncol. 2013, 42, 1533-1540. [CrossRef] [PubMed] 
50. Chen, L.; Zhang, J.; Feng, Y.; Li, R.; Sun, X.; Du, W.; Piao, X.; Wang, H.; Yang, D.; Sun, Y.; et al. MiR-410 Regulates MET to Influence the Proliferation and Invasion of Glioma. Int. J. Biochem. Cell Biol. 2012, 44, 1711-1717. [CrossRef] [PubMed]

51. Lim, L.; Balakrishnan, A.; Huskey, N.; Jones, K.D.; Jodari, M.; Ng, R.; Song, G.; Riordan, J.; Anderton, B.; Cheung, S.-T.; et al. MicroRNA-494 within an Oncogenic MicroRNA Megacluster Regulates G1/S Transition in Liver Tumorigenesis through Suppression of Mutated in Colorectal Cancer. Hepatology 2014, 59, 202-215. [CrossRef]

52. Chien, W.W.; Domenech, C.; Catallo, R.; Kaddar, T.; Magaud, J.-P.; Salles, G.; Ffrench, M. Cyclin-Dependent Kinase 1 Expression Is Inhibited by P16 INK4a at the Post-Transcriptional Level through the MicroRNA Pathway. Oncogene 2011, 30, 1880-1891. [CrossRef]

53. Dixon-McIver, A.; East, P.; Mein, C.A.; Cazier, J.-B.; Molloy, G.; Chaplin, T.; Andrew Lister, T.; Young, B.D.; Debernardi, S. Distinctive Patterns of MicroRNA Expression Associated with Karyotype in Acute Myeloid Leukaemia. PLoS ONE 2008, 3, e2141. [CrossRef] [PubMed]

54. Chabre, O.; Libé, R.; Assie, G.; Barreau, O.; Bertherat, J.; Bertagna, X.; Feige, J.-J.; Cherradi, N. Serum MiR-483-5p and MiR-195 Are Predictive of Recurrence Risk in Adrenocortical Cancer Patients. Endocr. Relat. Cancer 2013, 20, 579-594. [CrossRef] [PubMed]

55. Lussier, Y.A.; Xing, H.R.; Salama, J.K.; Khodarev, N.N.; Huang, Y.; Zhang, Q.; Khan, S.A.; Yang, X.; Hasselle, M.D.; Darga, T.E.; et al. MicroRNA Expression Characterizes Oligometastasis(Es). PLoS ONE 2011, 6, e28650. [CrossRef] [PubMed]

56. Lussier, Y.A.; Khodarev, N.N.; Regan, K.; Corbin, K.; Li, H.; Ganai, S.; Khan, S.A.; Gnerlich, J.L.; Gnerlich, J.; Darga, T.E.; et al. Oligo- and Polymetastatic Progression in Lung Metastasis(Es) Patients Is Associated with Specific MicroRNAs. PLoS ONE 2012, 7 , e50141. [CrossRef]

57. Yoshimoto, T.; Motoi, N.; Yamamoto, N.; Nagano, H.; Ushijima, M.; Matsuura, M.; Okumura, S.; Yamaguchi, T.; Fukayama, M.; Ishikawa, Y. Pulmonary Carcinoids and Low-Grade Gastrointestinal Neuroendocrine Tumors Show Common MicroRNA Expression Profiles, Different from Adenocarcinomas and Small Cell Carcinomas. Neuroendocrinology 2018, 106, 47-57. [CrossRef] [PubMed]

58. Mairinger, F.D.; Ting, S.; Werner, R.; Walter, R.F.H.; Hager, T.; Vollbrecht, C.; Christoph, D.; Worm, K.; Mairinger, T.; SheuGrabellus, S.-Y.; et al. Different Micro-RNA Expression Profiles Distinguish Subtypes of Neuroendocrine Tumors of the Lung: Results of a Profiling Study. Mod. Pathol. 2014, 27, 1632-1640. [CrossRef]

59. Deng, B.; Molina, J.; Aubry, M.C.; Sun, Z.; Wang, L.; Eckloff, B.W.; Vasmatzis, G.; You, M.; Wieben, E.D.; Jen, J.; et al. Clinical Biomarkers of Pulmonary Carcinoid Tumors in Never Smokers via Profiling MiRNA and Target MRNA. Cell Biosci. $2014,4,35$. [CrossRef] [PubMed]

60. Rapa, I.; Votta, A.; Felice, B.; Righi, L.; Giorcelli, J.; Scarpa, A.; Speel, E.-J.M.; Scagliotti, G.V.; Papotti, M.; Volante, M. Identification of MicroRNAs Differentially Expressed in Lung Carcinoid Subtypes and Progression. Neuroendocrinology 2015, 101, 246-255. [CrossRef]

61. Wong, J.J.M.; Ginter, P.S.; Tyryshkin, K.; Yang, X.; Nanayakkara, J.; Zhou, Z.; Tuschl, T.; Chen, Y.-T.; Renwick, N. Classifying Lung Neuroendocrine Neoplasms through MicroRNA Sequence Data Mining. Cancers 2020, 12, 2653. [CrossRef] [PubMed]

62. Zimmermann, N.; Knief, J.; Kacprowski, T.; Lazar-Karsten, P.; Keck, T.; Billmann, F.; Schmid, S.; Luley, K.; Lehnert, H.; Brabant, G.; et al. MicroRNA Analysis of Gastroenteropancreatic Neuroendocrine Tumors and Metastases. Oncotarget 2018, 9 , 28379-28390. [CrossRef] [PubMed]

63. Roldo, C.; Missiaglia, E.; Hagan, J.P.; Falconi, M.; Capelli, P.; Bersani, S.; Calin, G.A.; Volinia, S.; Liu, C.-G.; Scarpa, A.; et al. MicroRNA Expression Abnormalities in Pancreatic Endocrine and Acinar Tumors Are Associated with Distinctive Pathologic Features and Clinical Behavior. J. Clin. Oncol. 2006, 24, 4677-4684. [CrossRef] [PubMed]

64. Jiang, X.; Shan, A.; Su, Y.; Cheng, Y.; Gu, W.; Wang, W.; Ning, G.; Cao, Y. MiR-144/451 Promote Cell Proliferation via Targeting PTEN/AKT Pathway in Insulinomas. Endocrinology 2015, 156, 2429-2439. [CrossRef]

65. Zhou, H.-Q.; Chen, Q.-C.; Qiu, Z.-T.; Tan, W.-L.; Mo, C.-Q.; Gao, S.-W. Integrative MicroRNA-MRNA and Protein-Protein Interaction Analysis in Pancreatic Neuroendocrine Tumors. Eur. Rev. Med. Pharmacol. Sci. 2016, 20, 2842-2852. [PubMed]

66. Lee, Y.S.; Kim, H.; Kim, H.W.; Lee, J.-C.; Paik, K.-H.; Kang, J.; Kim, J.; Yoon, Y.-S.; Han, H.-S.; Sohn, I.; et al. High Expression of MicroRNA-196a Indicates Poor Prognosis in Resected Pancreatic Neuroendocrine Tumor. Medicine 2015, 94, e2224. [CrossRef]

67. Arvidsson, Y.; Rehammar, A.; Bergström, A.; Andersson, E.; Altiparmak, G.; Swärd, C.; Wängberg, B.; Kristiansson, E.; Nilsson, O. MiRNA Profiling of Small Intestinal Neuroendocrine Tumors Defines Novel Molecular Subtypes and Identifies MiR-375 as a Biomarker of Patient Survival. Mod. Pathol. 2018, 31, 1302-1317. [CrossRef]

68. Li, S.-C.; Essaghir, A.; Martijn, C.; Lloyd, R.V.; Demoulin, J.-B.; Oberg, K.; Giandomenico, V. Global MicroRNA Profiling of Well-Differentiated Small Intestinal Neuroendocrine Tumors. Mod. Pathol. 2013, 26, 685-696. [CrossRef]

69. Castro-Vega, L.J.; Letouzé, E.; Burnichon, N.; Buffet, A.; Disderot, P.-H.; Khalifa, E.; Loriot, C.; Elarouci, N.; Morin, A.; Menara, M.; et al. Multi-Omics Analysis Defines Core Genomic Alterations in Pheochromocytomas and Paragangliomas. Nat. Commun. 2015, 6, 6044. [CrossRef]

70. Tömböl, Z.; Eder, K.; Kovács, A.; Szabó, P.M.; Kulka, J.; Likó, I.; Zalatnai, A.; Rácz, G.; Tóth, M.; Patócs, A.; et al. MicroRNA Expression Profiling in Benign (Sporadic and Hereditary) and Recurring Adrenal Pheochromocytomas. Mod. Pathol. 2010, 23, 1583-1595. [CrossRef] [PubMed]

71. De Cubas, A.A.; Leandro-García, L.J.; Schiavi, F.; Mancikova, V.; Comino-Méndez, I.; Inglada-Pérez, L.; Perez-Martinez, M.; Ibarz, N.; Ximénez-Embún, P.; López-Jiménez, E.; et al. Integrative Analysis of MiRNA and MRNA Expression Profiles in Pheochromocytoma and Paraganglioma Identifies Genotype-Specific Markers and Potentially Regulated Pathways. Endocr. Relat. Cancer 2013, 20, 477-493. [CrossRef] 
72. Meyer-Rochow, G.Y.; Jackson, N.E.; Conaglen, J.V.; Whittle, D.E.; Kunnimalaiyaan, M.; Chen, H.; Westin, G.; Sandgren, J.; Stålberg, P.; Khanafshar, E.; et al. MicroRNA Profiling of Benign and Malignant Pheochromocytomas Identifies Novel Diagnostic and Therapeutic Targets. Endocr. Relat. Cancer 2010, 17, 835-846. [CrossRef]

73. Calsina, B.; Castro-Vega, L.J.; Torres-Pérez, R.; Inglada-Pérez, L.; Currás-Freixes, M.; Roldán-Romero, J.M.; Mancikova, V.; Letón, R.; Remacha, L.; Santos, M.; et al. Integrative Multi-Omics Analysis Identifies a Prognostic MiRNA Signature and a Targetable MiR-21-3p/TSC2/MTOR Axis in Metastatic Pheochromocytoma/Paraganglioma. Theranostics 2019, 9, $4946-4958$. [CrossRef] [PubMed]

74. Tömböl, Z.; Szabó, P.M.; Molnár, V.; Wiener, Z.; Tölgyesi, G.; Horányi, J.; Riesz, P.; Reismann, P.; Patócs, A.; Likó, I.; et al. Integrative Molecular Bioinformatics Study of Human Adrenocortical Tumors: MicroRNA, Tissue-Specific Target Prediction, and Pathway Analysis. Endocr. Relat. Cancer 2009, 16, 895-906. [CrossRef] [PubMed]

75. Özata, D.M.; Caramuta, S.; Velázquez-Fernández, D.; Akçakaya, P.; Xie, H.; Höög, A.; Zedenius, J.; Bäckdahl, M.; Larsson, C.; Lui, W.-O. The Role of MicroRNA Deregulation in the Pathogenesis of Adrenocortical Carcinoma. Endocr. Relat. Cancer 2011, 18, 643-655. [CrossRef]

76. Assié, G.; Letouzé, E.; Fassnacht, M.; Jouinot, A.; Luscap, W.; Barreau, O.; Omeiri, H.; Rodriguez, S.; Perlemoine, K.; René-Corail, F.; et al Integrated Genomic Characterization of Adrenocortical Carcinoma. Nat. Genet. 2014, 46, 607-612. [CrossRef] [PubMed]

77. Mao, Z.-G.; He, D.-S.; Zhou, J.; Yao, B.; Xiao, W.-W.; Chen, C.-H.; Zhu, Y.-H.; Wang, H.-J. Differential Expression of MicroRNAs in GH-Secreting Pituitary Adenomas. Diagn. Pathol. 2010, 5, 79. [CrossRef]

78. D’Angelo, D.; Palmieri, D.; Mussnich, P.; Roche, M.; Wierinckx, A.; Raverot, G.; Fedele, M.; Croce, C.M.; Trouillas, J.; Fusco, A. Altered MicroRNA Expression Profile in Human Pituitary GH Adenomas: Down-Regulation of MiRNA Targeting HMGA1, HMGA2, and E2F1. J. Clin. Endocrinol. Metab. 2012, 97, E1128-E1138. [CrossRef]

79. Bottoni, A.; Zatelli, M.C.; Ferracin, M.; Tagliati, F.; Piccin, D.; Vignali, C.; Calin, G.A.; Negrini, M.; Croce, C.M.; Degli Uberti, E.C. Identification of Differentially Expressed MicroRNAs by Microarray: A Possible Role for MicroRNA Genes in Pituitary Adenomas. J. Cell. Physiol. 2007, 210, 370-377. [CrossRef] [PubMed]

80. Butz, H.; Liko, I.; Boyle, B.; Czirjak, S.; Igaz, P.; Patocs, A.; Racz, K. MicroRNA Expression in Human Sporadic Pituitary Adenomas. Endocr. Abstr. 2009, 20, 566.

81. Cheunsuchon, P.; Zhou, Y.; Zhang, X.; Lee, H.; Chen, W.; Nakayama, Y.; Rice, K.A.; Tessa Hedley-Whyte, E.; Swearingen, B.; Klibanski, A. Silencing of the Imprinted DLK1-MEG3 Locus in Human Clinically Nonfunctioning Pituitary Adenomas. Am. J. Pathol. 2011, 179, 2120-2130. [CrossRef]

82. He, Z.; Chen, L.; Hu, X.; Tang, J.; He, L.; Hu, J.; Fei, F.; Wang, Q. Next-Generation Sequencing of MicroRNAs Reveals a Unique Expression Pattern in Different Types of Pituitary Adenomas. Endocr. J. 2019, 66, 709-722. [CrossRef]

83. Gentilin, E.; Tagliati, F.; Filieri, C.; Molè, D.; Minoia, M.; Rosaria Ambrosio, M.; Degli Uberti, E.C.; Zatelli, M.C. MiR-26a Plays an Important Role in Cell Cycle Regulation in ACTH-Secreting Pituitary Adenomas by Modulating Protein Kinase C $\delta$. Endocrinology 2013, 154, 1690-1700. [CrossRef]

84. Amaral, F.C.; Torres, N.; Saggioro, F.; Neder, L.; Machado, H.R.; Silva, W.A.; Moreira, A.C.; Castro, M. MicroRNAs Differentially Expressed in ACTH-Secreting Pituitary Tumors. J. Clin. Endocrinol. Metab. 2009, 94, 320-323. [CrossRef] [PubMed]

85. Stilling, G.; Sun, Z.; Zhang, S.; Jin, L.; Righi, A.; Kovācs, G.; Korbonits, M.; Scheithauer, B.W.; Kovacs, K.; Lloyd, R.V. MicroRNA Expression in ACTH-Producing Pituitary Tumors: Up-Regulation of MicroRNA-122 and -493 in Pituitary Carcinomas. Endocrine 2010, 38, 67-75. [CrossRef] [PubMed]

86. Müssnich, P.; Raverot, G.; Jaffrain-Rea, M.-L.; Fraggetta, F.; Wierinckx, A.; Trouillas, J.; Fusco, A.; D’ Angelo, D. Downregulation of MiR-410 Targeting the Cyclin B1 Gene Plays a Role in Pituitary Gonadotroph Tumors. Cell Cycle 2015, 14, $2590-2597$. [CrossRef] [PubMed]

87. Chen, Y.; Li, Q.; Wang, C.; Su, Z.; Li, W.; Chen, X.; Wu, Z. Differential expression analysis of prolactinoma-related microRNAs. Zhonghua Yi Xue Za Zhi 2012, 92, 320-323. [PubMed]

88. Darvasi, O.; Szabo, P.M.; Nemeth, K.; Szabo, K.; Spisak, S.; Liko, I.; Czirjak, S.; Racz, K.; Igaz, P.; Patocs, A.; et al. Limitations of High Throughput Methods for MiRNA Expression Profiles in Non-Functioning Pituitary Adenomas. Pathol. Oncol. Res. 2019, 25, 169-182. [CrossRef] [PubMed]

89. Butz, H.; Likó, I.; Czirják, S.; Igaz, P.; Korbonits, M.; Rácz, K.; Patócs, A. MicroRNA Profile Indicates Downregulation of the TGF $\beta$ Pathway in Sporadic Non-Functioning Pituitary Adenomas. Pituitary 2011, 14, 112-124. [CrossRef]

90. Liang, H.; Wang, R.; Diao, C.; Li, J.; Su, J.; Zhang, S. The PTTG1-Targeting MiRNAs MiR-329, MiR-300, MiR-381, and MiR-655 Inhibit Pituitary Tumor Cell Tumorigenesis and Are Involved in a P53/PTTG1 Regulation Feedback Loop. Oncotarget 2015, 6, 29413-29427. [CrossRef]

91. Krokker, L.; Nyírő, G.; Reiniger, L.; Darvasi, O.; Szücs, N.; Czirják, S.; Tóth, M.; Igaz, P.; Patócs, A.; Butz, H. Differentially Expressed MiRNAs Influence Metabolic Processes in Pituitary Oncocytoma. Neurochem. Res. 2019. [CrossRef]

92. Lassalle, S.; Zangari, J.; Popa, A.; Ilie, M.; Hofman, V.; Long, E.; Patey, M.; Tissier, F.; Belléannée, G.; Trouette, H.; et al. MicroRNA375/SEC23A as Biomarkers of the in Vitro Efficacy of Vandetanib. Oncotarget 2016, 7, 30461-30478. [CrossRef] [PubMed]

93. Hudson, J.; Duncavage, E.; Tamburrino, A.; Salerno, P.; Xi, L.; Raffeld, M.; Moley, J.; Chernock, R.D. Over Expression of MiR-10a and MiR-375 and down Regulation of YAP1 in Medullary Thyroid Carcinoma. Exp. Mol. Pathol. 2013, 95, 62-67. [CrossRef] [PubMed] 
94. Nikiforova, M.N.; Tseng, G.C.; Steward, D.; Diorio, D.; Nikiforov, Y.E. MicroRNA Expression Profiling of Thyroid Tumors: Biological Significance and Diagnostic Utility. J. Clin. Endocrinol. Metab. 2008, 93, 1600-1608. [CrossRef]

95. Geraldo, M.V.; Nakaya, H.I.; Kimura, E.T. Down-Regulation of 14q32-Encoded MiRNAs and Tumor Suppressor Role for MiR-654-3p in Papillary Thyroid Cancer. Oncotarget 2017, 8, 9597-9607. [CrossRef]

96. Rosignolo, F.; Sponziello, M.; Giacomelli, L.; Russo, D.; Pecce, V.; Biffoni, M.; Bellantone, R.; Lombardi, C.P.; Lamartina, L.; Grani, G.; et al. Identification of Thyroid-Associated Serum MicroRNA Profiles and Their Potential Use in Thyroid Cancer Follow-Up. J. Endocr. Soc. 2017, 1, 3-13. [CrossRef]

97. Tetzlaff, M.T.; Liu, A.; Xu, X.; Master, S.R.; Baldwin, D.A.; Tobias, J.W.; Livolsi, V.A.; Baloch, Z.W. Differential Expression of MiRNAs in Papillary Thyroid Carcinoma Compared to Multinodular Goiter Using Formalin Fixed Paraffin Embedded Tissues. Endocr. Pathol. 2007, 18, 163-173. [CrossRef]

98. Linwah, Y.; Kelly, L.; Yongli, S.; Armstrong, M.J.; Nikiforov, Y.E.; Carty, S.E.; Nikiforova, M.N. MicroRNA Signature Distinguishes the Degree of Aggressiveness of Papillary Thyroid Carcinoma. Ann. Surg. Oncol. 2011, 18, 2035-2041. [CrossRef]

99. Jacques, C.; Guillotin, D.; Fontaine, J.-F.; Franc, B.; Mirebeau-Prunier, D.; Fleury, A.; Malthiery, Y.; Savagner, F. DNA Microarray and MiRNA Analyses Reinforce the Classification of Follicular Thyroid Tumors. J. Clin. Endocrinol. Metab. 2013, 98, E981-E989. [CrossRef] [PubMed]

100. Lassalle, S.; Hofman, V.; Ilie, M.; Bonnetaud, C.; Puisségur, M.-P.; Brest, P.; Loubatier, C.; Guevara, N.; Bordone, O.; Cardinaud, B.; et al. Can the MicroRNA Signature Distinguish between Thyroid Tumors of Uncertain Malignant Potential and Other Well-Differentiated Tumors of the Thyroid Gland? Endocr. Relat. Cancer 2011, 18, 579-594. [CrossRef]

101. Mancikova, V.; Castelblanco, E.; Pineiro-Yanez, E.; Perales-Paton, J.; de Cubas, A.A.; Inglada-Perez, L.; Matias-Guiu, X.; Capel, I.; Bella, M.; Lerma, E.; et al. MicroRNA Deep-Sequencing Reveals Master Regulators of Follicular and Papillary Thyroid Tumors. Mod. Pathol. 2015, 28, 748-757. [CrossRef]

102. Peng, Y.; Li, C.; Luo, D.-C.; Ding, J.-W.; Zhang, W.; Pan, G. Expression Profile and Clinical Significance of MicroRNAs in Papillary Thyroid Carcinoma. Molecules 2014, 19, 11586-11599. [CrossRef] [PubMed]

103. Riesco-Eizaguirre, G.; Wert-Lamas, L.; Perales-Patón, J.; Sastre-Perona, A.; Fernández, L.P.; Santisteban, P. The MiR-146b3p/PAX8/NIS Regulatory Circuit Modulates the Differentiation Phenotype and Function of Thyroid Cells during Carcinogenesis. Cancer Res. 2015, 75, 4119-4130. [CrossRef]

104. Saiselet, M.; Gacquer, D.; Spinette, A.; Craciun, L.; Decaussin-Petrucci, M.; Andry, G.; Detours, V.; Maenhaut, C. New Global Analysis of the MicroRNA Transcriptome of Primary Tumors and Lymph Node Metastases of Papillary Thyroid Cancer. BMC Genom. 2015, 16. [CrossRef] [PubMed]

105. Swierniak, M.; Wojcicka, A.; Czetwertynska, M.; Stachlewska, E.; Maciag, M.; Wiechno, W.; Gornicka, B.; Bogdanska, M.; Koperski, L.; de la Chapelle, A.; et al. In-Depth Characterization of the MicroRNA Transcriptome in Normal Thyroid and Papillary Thyroid Carcinoma. J. Clin. Endocrinol. Metab. 2013, 98, E1401-E1409. [CrossRef] [PubMed]

106. Rossing, M.; Borup, R.; Henao, R.; Winther, O.; Vikesaa, J.; Niazi, O.; Godballe, C.; Krogdahl, A.; Glud, M.; Hjort-Sørensen, C.; et al. Down-Regulation of MicroRNAs Controlling Tumourigenic Factors in Follicular Thyroid Carcinoma. J. Mol. Endocrinol. 2012, 48, 11-23. [CrossRef] [PubMed]

107. Dettmer, M.; Vogetseder, A.; Durso, M.B.; Moch, H.; Komminoth, P.; Perren, A.; Nikiforov, Y.E.; Nikiforova, M.N. MicroRNA Expression Array Identifies Novel Diagnostic Markers for Conventional and Oncocytic Follicular Thyroid Carcinomas. J. Clin. Endocrinol. Metab. 2013, 98, E1-E7. [CrossRef]

108. Wojtas, B.; Ferraz, C.; Stokowy, T.; Hauptmann, S.; Lange, D.; Dralle, H.; Musholt, T.; Jarzab, B.; Paschke, R.; Eszlinger, M. Differential MiRNA Expression Defines Migration and Reduced Apoptosis in Follicular Thyroid Carcinomas. Mol. Cell. Endocrinol. 2014, 388, 1-9. [CrossRef]

109. Hébrant, A.; Floor, S.; Saiselet, M.; Antoniou, A.; Desbuleux, A.; Snyers, B.; La, C.; de Saint Aubain, N.; Leteurtre, E.; Andry, G.; et al. MiRNA Expression in Anaplastic Thyroid Carcinomas. PLoS ONE 2014, 9. [CrossRef]

110. Visone, R.; Pallante, P.; Vecchione, A.; Cirombella, R.; Ferracin, M.; Ferraro, A.; Volinia, S.; Coluzzi, S.; Leone, V.; Borbone, E.; et al. Specific MicroRNAs Are Downregulated in Human Thyroid Anaplastic Carcinomas. Oncogene 2007, 26, 7590-7595. [CrossRef]

111. Boufraqech, M.; Nilubol, N.; Zhang, L.; Gara, S.K.; Sadowski, S.M.; Mehta, A.; He, M.; Davis, S.; Dreiling, J.; Copland, J.A.; et al. MiR30a Inhibits LOX Expression and Anaplastic Thyroid Cancer Progression. Cancer Res. 2015, 75, 367-377. [CrossRef]

112. Braun, J.; Hoang-Vu, C.; Dralle, H.; Hüttelmaier, S. Downregulation of MicroRNAs Directs the EMT and Invasive Potential of Anaplastic Thyroid Carcinomas. Oncogene 2010, 29, 4237-4244. [CrossRef]

113. Yao, J.C.; Hassan, M.; Phan, A.; Dagohoy, C.; Leary, C.; Mares, J.E.; Abdalla, E.K.; Fleming, J.B.; Vauthey, J.-N.; Rashid, A.; et al. One Hundred Years after "Carcinoid": Epidemiology of and Prognostic Factors for Neuroendocrine Tumors in 35,825 Cases in the United States. J. Clin. Oncol. 2008, 26, 3063-3072. [CrossRef]

114. Hendifar, A.E.; Marchevsky, A.M.; Tuli, R. Neuroendocrine Tumors of the Lung: Current Challenges and Advances in the Diagnosis and Management of Well-Differentiated Disease. J. Thorac. Oncol. 2017, 12, 425-436. [CrossRef] [PubMed]

115. Malczewska, A.; Kidd, M.; Matar, S.; Kos-Kudla, B.; Modlin, I.M. A Comprehensive Assessment of the Role of MiRNAs as Biomarkers in Gastroenteropancreatic Neuroendocrine Tumors. Neuroendocrinology 2018, 107, 73-90. [CrossRef]

116. Zatelli, M.C.; Grossrubatscher, E.M.; Guadagno, E.; Sciammarella, C.; Faggiano, A.; Colao, A. Circulating Tumor Cells and MiRNAs as Prognostic Markers in Neuroendocrine Neoplasms. Endocr. Relat. Cancer 2017, 24, R223-R237. [CrossRef] [PubMed] 
117. Abuhatzira, L.; Xu, H.; Tahhan, G.; Boulougoura, A.; Schäffer, A.A.; Notkins, A.L. Multiple microRNAs within the $14 q 32$ cluster target the mRNAs of major type 1 diabetes autoantigens IA-2, IA-2 $\beta$, and GAD65. FASEB J. 2015, 29, $4374-4383$. [CrossRef] [PubMed]

118. Miller, H.C.; Frampton, A.E.; Malczewska, A.; Ottaviani, S.; Stronach, E.A.; Flora, R.; Kaemmerer, D.; Schwach, G.; Pfragner, R.; Faiz, O.; et al. MicroRNAs Associated with Small Bowel Neuroendocrine Tumours and Their Metastases. Endocr. Relat. Cancer 2016, 23, 711-726. [CrossRef] [PubMed]

119. Ruebel, K.; Leontovich, A.A.; Stilling, G.A.; Zhang, S.; Righi, A.; Jin, L.; Lloyd, R.V. MicroRNA Expression in Ileal Carcinoid Tumors: Downregulation of MicroRNA-133a with Tumor Progression. Mod. Pathol. 2010, 23, 367-375. [CrossRef] [PubMed]

120. Heverhagen, A.E.; Legrand, N.; Wagner, V.; Fendrich, V.; Bartsch, D.K.; Slater, E.P. Overexpression of MicroRNA MiR-7$5 p$ Is a Potential Biomarker in Neuroendocrine Neoplasms of the Small Intestine. Neuroendocrinology 2018, 106, 312-317. [CrossRef] [PubMed]

121. Hamfjord, J.; Stangeland, A.M.; Hughes, T.; Skrede, M.L.; Tveit, K.M.; Ikdahl, T.; Kure, E.H. Differential Expression of MiRNAs in Colorectal Cancer: Comparison of Paired Tumor Tissue and Adjacent Normal Mucosa Using High-Throughput Sequencing. PLoS ONE 2012, 7, e34150. [CrossRef] [PubMed]

122. Castro-Vega, L.J.; Lepoutre-Lussey, C.; Gimenez-Roqueplo, A.-P.; Favier, J. Rethinking Pheochromocytomas and Paragangliomas from a Genomic Perspective. Oncogene 2016, 35, 1080-1089. [CrossRef] [PubMed]

123. Pereira, B.D.; Luiz, H.V.; Ferreira, A.G.; Portugal, J. Genetics of Pheochromocytoma and Paraganglioma. In Paraganglioma: A Multidisciplinary Approach; Mariani-Costantini, R., Ed.; Codon Publications: Brisbane, Austrilia, 2019; ISBN 978-0-9944381-7-1.

124. Patterson, E.; Webb, R.; Weisbrod, A.; Bian, B.; He, M.; Zhang, L.; Holloway, A.K.; Krishna, R.; Nilubol, N.; Pacak, K.; et al. The MicroRNA Expression Changes Associated with Malignancy and SDHB Mutation in Pheochromocytoma. Endocr. Relat. Cancer 2012, 19, 157-166. [CrossRef] [PubMed]

125. Igaz, P.; Igaz, I.; Nagy, Z.; Nyírő, G.; Szabó, P.M.; Falus, A.; Patócs, A.; Rácz, K. MicroRNAs in Adrenal Tumors: Relevance for Pathogenesis, Diagnosis, and Therapy. Cell. Mol. Life Sci. 2015, 72, 417-428. [CrossRef] [PubMed]

126. Robertson, S.; MacKenzie, S.M.; Alvarez-Madrazo, S.; Diver, L.A.; Lin, J.; Stewart, P.M.; Fraser, R.; Connell, J.M.; Davies, E. MicroRNA-24 Is a Novel Regulator of Aldosterone and Cortisol Production in the Human Adrenal Cortex. Hypertension 2013, 62, 572-578. [CrossRef]

127. MacKenzie, S.M.; van Kralingen, J.; Martin, H.; Davies, E. MicroRNAs in Aldosterone Production and Action. Aldosterone Miner. Recept. Cell Biol. Transl. Med. 2019. [CrossRef]

128. He, J.; Cao, Y.; Su, T.; Jiang, Y.; Jiang, L.; Zhou, W.; Zhang, C.; Wang, W.; Ning, G. Downregulation of MiR-375 in AldosteroneProducing Adenomas Promotes Tumour Cell Growth via MTDH. Clin. Endocrinol. 2015, 83, 581-589. [CrossRef]

129. Peng, K.-Y.; Chang, H.-M.; Lin, Y.-F.; Chan, C.-K.; Chang, C.-H.; Chueh, S.-C.J.; Yang, S.-Y.; Huang, K.-H.; Lin, Y.-H.; Wu, V.-C.; et al. MiRNA-203 Modulates Aldosterone Levels and Cell Proliferation by Targeting Wnt5a in Aldosterone-Producing Adenomas. J. Clin. Endocrinol. Metab. 2018, 103, 3737-3747. [CrossRef]

130. Nakano, Y.; Yoshimoto, T.; Watanabe, R.; Murakami, M.; Fukuda, T.; Saito, K.; Fujii, Y.; Akashi, T.; Tanaka, T.; Yamada, T.; et al. MiRNA299 Involvement in CYP11B2 Expression in Aldosterone-Producing Adenoma. Eur. J. Endocrinol. 2019, 181, 69-78. [CrossRef]

131. Patterson, E.E.; Holloway, A.K.; Weng, J.; Fojo, T.; Kebebew, E. MicroRNA Profiling of Adrenocortical Tumors Reveals MiR-483 as a Marker of Malignancy. Cancer 2011, 117, 1630-1639. [CrossRef]

132. Kwok, G.T.Y.; Zhao, J.T.; Glover, A.R.; Gill, A.J.; Clifton-Bligh, R.; Robinson, B.G.; Ip, J.C.Y.; Sidhu, S.B. MicroRNA-431 as a Chemosensitizer and Potentiator of Drug Activity in Adrenocortical Carcinoma. Oncologist 2019, 24, e241-e250. [CrossRef] [PubMed]

133. Turányi, E.; Dezso, K.; Paku, S.; Nagy, P. DLK Is a Novel Immunohistochemical Marker for Adrenal Gland Tumors. Virchows Arch. 2009, 455, 295-299. [CrossRef] [PubMed]

134. Aflorei, E.D.; Korbonits, M. Epidemiology and Etiopathogenesis of Pituitary Adenomas. J. Neurooncol. 2014, 117, 379-394. [CrossRef] [PubMed]

135. Feng, Y.; Mao, Z.-G.; Wang, X.; Du, Q.; Jian, M.; Zhu, D.; Xiao, Z.; Wang, H.-J.; Zhu, Y.-H. MicroRNAs and Target Genes in Pituitary Adenomas. Horm. Metab. Res. 2018, 50, 179-192. [CrossRef]

136. Wierinckx, A.; Roche, M.; Legras-Lachuer, C.; Trouillas, J.; Raverot, G.; Lachuer, J. MicroRNAs in Pituitary Tumors. Mol. Cell. Endocrinol. 2017, 456, 51-61. [CrossRef]

137. Vicchio, T.M.; Aliquò, F.; Ruggeri, R.M.; Ragonese, M.; Giuffrida, G.; Cotta, O.R.; Spagnolo, F.; Torre, M.L.; Alibrandi, A.; Asmundo, A.; et al. MicroRNAs Expression in Pituitary Tumors: Differences Related to Functional Status, Pathological Features, and Clinical Behavior. J. Endocrinol. Investig. 2020, 43, 947-958. [CrossRef] [PubMed]

138. Palumbo, T.; Faucz, F.R.; Azevedo, M.; Xekouki, P.; Iliopoulos, D.; Stratakis, C.A. Functional Screen Analysis Reveals MiR-26b and MiR-128 as Central Regulators of Pituitary Somatomammotrophic Tumor Growth through Activation of the PTEN-AKT Pathway. Oncogene 2013, 32, 1651-1659. [CrossRef]

139. Beylerli, O.; Beeraka, N.M.; Gareev, I.; Pavlov, V.; Yang, G.; Liang, Y.; Aliev, G. MiRNAs as Noninvasive Biomarkers and Therapeutic Agents of Pituitary Adenomas. Int. J. Mol. Sci. 2020, 21, 7287. [CrossRef]

140. Gejman, R.; Batista, D.L.; Zhong, Y.; Zhou, Y.; Zhang, X.; Swearingen, B.; Stratakis, C.A.; Hedley-Whyte, E.T.; Klibanski, A. Selective Loss of MEG3 Expression and Intergenic Differentially Methylated Region Hypermethylation in the MEG3/DLK1 Locus in Human Clinically Nonfunctioning Pituitary Adenomas. J. Clin. Endocrinol. Metab. 2008, 93, 4119-4125. [CrossRef] 
141. Zhao, J.; Dahle, D.; Zhou, Y.; Zhang, X.; Klibanski, A. Hypermethylation of the Promoter Region Is Associated with the Loss of MEG3 Gene Expression in Human Pituitary Tumors. J. Clin. Endocrinol. Metab. 2005, 90, 2179-2186. [CrossRef] [PubMed]

142. Jin, L.; Riss, D.; Ruebel, K.; Kajita, S.; Scheithauer, B.W.; Horvath, E.; Kovacs, K.; Lloyd, R.V. Galectin-3 Expression in Functioning and Silent ACTH-Producing Adenomas. Endocr. Pathol. 2005, 16, 107-114. [CrossRef] [PubMed]

143. Riss, D.; Jin, L.; Qian, X.; Bayliss, J.; Scheithauer, B.W.; Young, W.F.; Vidal, S.; Kovacs, K.; Raz, A.; Lloyd, R.V. Differential Expression of Galectin-3 in Pituitary Tumors. Cancer Res. 2003, 63, 2251-2255.

144. Ruebel, K.H.; Jin, L.; Qian, X.; Scheithauer, B.W.; Kovacs, K.; Nakamura, N.; Zhang, H.; Raz, A.; Lloyd, R.V. Effects of DNA Methylation on Galectin-3 Expression in Pituitary Tumors. Cancer Res. 2005, 65, 1136-1140. [CrossRef]

145. Zhang, H.-Y.; Jin, L.; Stilling, G.A.; Ruebel, K.H.; Coonse, K.; Tanizaki, Y.; Raz, A.; Lloyd, R.V. RUNX1 and RUNX2 Upregulate Galectin-3 Expression in Human Pituitary Tumors. Endocrine 2009, 35, 101-111. [CrossRef]

146. Raue, F.; Frank-Raue, K. Epidemiology and Clinical Presentation of Medullary Thyroid Carcinoma. Recent Results Cancer Res. 2015, 204, 61-90. [CrossRef] [PubMed]

147. Malek, A.; Sleptsov, I.E.; Cheburkin, Y.V.; Roman, S.; Kolesnikov, N. MiRNA as Potential Tool for Thyroid Cancer Diagnostics and Follow up: Practical Considerations. JSM Thyroid Disord. Manag. 2017, 2, 1007.

148. Romeo, P.; Colombo, C.; Granata, R.; Calareso, G.; Gualeni, A.V.; Dugo, M.; De Cecco, L.; Rizzetti, M.G.; Zanframundo, A.; Aiello, A.; et al. Circulating MiR-375 as a Novel Prognostic Marker for Metastatic Medullary Thyroid Cancer Patients. Endocr. Relat. Cancer 2018, 25, 217-231. [CrossRef]

149. Saiselet, M.; Pita, J.M.; Augenlicht, A.; Dom, G.; Tarabichi, M.; Fimereli, D.; Dumont, J.E.; Detours, V.; Maenhaut, C. MiRNA Expression and Function in Thyroid Carcinomas: A Comparative and Critical Analysis and a Model for Other Cancers. Oncotarget 2016, 7, 52475-52492. [CrossRef]

150. Boufraqech, M.; Klubo-Gwiezdzinska, J.; Kebebew, E. MicroRNAs in the Thyroid. Best Pract. Res. Clin. Endocrinol. Metab. 2016, 30, 603-619. [CrossRef]

151. Fiore, R.; Khudayberdiev, S.; Christensen, M.; Siegel, G.; Flavell, S.W.; Kim, T.-K.; Greenberg, M.E.; Schratt, G. Mef2-Mediated Transcription of the MiR379-410 Cluster Regulates Activity-Dependent Dendritogenesis by Fine-Tuning Pumilio2 Protein Levels. EMBO J. 2009, 28, 697-710. [CrossRef] [PubMed]

152. Aavik, E.; Lumivuori, H.; Leppänen, O.; Wirth, T.; Häkkinen, S.-K.; Bräsen, J.-H.; Beschorner, U.; Zeller, T.; Braspenning, M.; van Criekinge, W.; et al. Global DNA Methylation Analysis of Human Atherosclerotic Plaques Reveals Extensive Genomic Hypomethylation and Reactivation at Imprinted Locus $14 q 32$ Involving Induction of a MiRNA Cluster. Eur. Heart J. 2015, 36, 993-1000. [CrossRef] [PubMed]

153. Romitti, M.; Wajner, S.M.; Zennig, N.; Goemann, I.M.; Bueno, A.L.; Meyer, E.L.S.; Maia, A.L. Increased Type 3 Deiodinase Expression in Papillary Thyroid Carcinoma. Thyroid 2012, 22, 897-904. [CrossRef] [PubMed]

154. Greife, A.; Knievel, J.; Ribarska, T.; Niegisch, G.; Schulz, W.A. Concomitant Downregulation of the Imprinted Genes DLK1 and MEG3 at 14q32.2 by Epigenetic Mechanisms in Urothelial Carcinoma. Clin. Epigenetics 2014, 6, 29. [CrossRef]

155. Jishnu, P.V.; Jayaram, P.; Shukla, V.; Varghese, V.K.; Pandey, D.; Sharan, K.; Chakrabarty, S.; Satyamoorthy, K.; Kabekkodu, S.P. Prognostic Role of 14q32.31 MiRNA Cluster in Various Carcinomas: A Systematic Review and Meta-Analysis. Clin. Exp. Metastasis 2020, 37, 31-46. [CrossRef] [PubMed]

156. Shu, J.; Li, L.; Sarver, A.E.; Pope, E.A.; Varshney, J.; Thayanithy, V.; Spector, L.; Largaespada, D.A.; Steer, C.J.; Subramanian, S. Imprinting Defects at Human 14q32 Locus Alters Gene Expression and Is Associated with the Pathobiology of Osteosarcoma. Oncotarget 2016, 7, 21298-21314. [CrossRef] [PubMed]

157. Manodoro, F.; Marzec, J.; Chaplin, T.; Miraki-Moud, F.; Moravcsik, E.; Jovanovic, J.V.; Wang, J.; Iqbal, S.; Taussig, D.; Grimwade, D.; et al. Loss of Imprinting at the 14q32 Domain Is Associated with MicroRNA Overexpression in Acute Promyelocytic Leukemia. Blood 2014, 123, 2066-2074. [CrossRef]

158. Romitti, M.; Wajner, S.M.; Ceolin, L.; Ferreira, C.V.; Ribeiro, R.V.P.; Rohenkohl, H.C.; Weber, S.D.S.; Lopez, P.L.D.C.; Fuziwara, C.S.; Kimura, E.T.; et al. MAPK and SHH Pathways Modulate Type 3 Deiodinase Expression in Papillary Thyroid Carcinoma. Endocr. Relat. Cancer 2016, 23, 135-146. [CrossRef]

159. Gardiner, E.; Beveridge, N.J.; Wu, J.Q.; Carr, V.; Scott, R.J.; Tooney, P.A.; Cairns, M.J. Imprinted DLK1-DIO3 Region of 14q32 Defines a Schizophrenia-Associated MiRNA Signature in Peripheral Blood Mononuclear Cells. Mol. Psychiatry 2012, 17, 827-840. [CrossRef]

160. Stark, K.L.; Xu, B.; Bagchi, A.; Lai, W.-S.; Liu, H.; Hsu, R.; Wan, X.; Pavlidis, P.; Mills, A.A.; Karayiorgou, M.; et al. Altered Brain MicroRNA Biogenesis Contributes to Phenotypic Deficits in a 22q11-Deletion Mouse Model. Nat. Genet. 2008, 40, 751-760. [CrossRef]

161. Schaefer, A.; Im, H.-I.; Venø, M.T.; Fowler, C.D.; Min, A.; Intrator, A.; Kjems, J.; Kenny, P.J.; O'Carroll, D.; Greengard, P. Argonaute 2 in Dopamine 2 Receptor-Expressing Neurons Regulates Cocaine Addiction. J. Exp. Med. 2010, 207, 1843-1851. [CrossRef]

162. Diederichs, S.; Haber, D.A. Dual Role for Argonautes in MicroRNA Processing and Posttranscriptional Regulation of MicroRNA Expression. Cell 2007, 131, 1097-1108. [CrossRef] [PubMed]

163. O'Carroll, D.; Mecklenbrauker, I.; Das, P.P.; Santana, A.; Koenig, U.; Enright, A.J.; Miska, E.A.; Tarakhovsky, A. A SlicerIndependent Role for Argonaute 2 in Hematopoiesis and the MicroRNA Pathway. Genes Dev. 2007, 21, 1999-2004. [CrossRef]

164. Welten, S.M.J.; de Vries, M.R.; Peters, E.A.B.; Agrawal, S.; Quax, P.H.A.; Nossent, A.Y. Inhibition of Mef2a Enhances Neovascularization via Post-Transcriptional Regulation of 14q32 MicroRNAs MiR-329 and MiR-494. Mol. Ther. Nucleic Acids 2017, 7, 61-70. [CrossRef] [PubMed] 
165. Downie Ruiz Velasco, A.; Welten, S.M.J.; Goossens, E.A.C.; Quax, P.H.A.; Rappsilber, J.; Michlewski, G.; Nossent, A.Y. Posttranscriptional Regulation of 14q32 MicroRNAs by the CIRBP and HADHB during Vascular Regeneration after Ischemia. Mol. Ther. Nucleic Acids 2019, 14, 329-338. [CrossRef] [PubMed]

166. Rosa, A.L.; Wu, Y.-Q.; Kwabi-Addo, B.; Coveler, K.J.; Reid Sutton, V.; Shaffer, L.G. Allele-Specific Methylation of a Functional CTCF Binding Site Upstream of MEG3 in the Human Imprinted Domain of 14q32. Chromosome Res. 2005, 13, 809-818. [CrossRef] [PubMed]

167. Bell, A.C.; West, A.G.; Felsenfeld, G. The Protein CTCF Is Required for the Enhancer Blocking Activity of Vertebrate Insulators. Cell 1999, 98, 387-396. [CrossRef]

168. Szabó, P.E.; Tang, S.-H.E.; Rentsendorj, A.; Pfeifer, G.P.; Mann, J.R. Maternal-Specific Footprints at Putative CTCF Sites in the H19 Imprinting Control Region Give Evidence for Insulator Function. Curr. Biol. 2000, 10, 607-610. [CrossRef]

169. Welten, S.M.J.; Bastiaansen, A.J.N.M.; de Jong, R.C.M.; de Vries, M.R.; Peters, E.A.B.; Boonstra, M.C.; Sheikh, S.P.; La Monica, N.; Kandimalla, E.R.; Quax, P.H.A.; et al. Inhibition of 14q32 MicroRNAs MiR-329, MiR-487b, MiR-494, and MiR-495 Increases Neovascularization and Blood Flow Recovery after Ischemia. Circ. Res. 2014, 115, 696-708. [CrossRef]

170. Gupta, G.P.; Massagué, J. Cancer Metastasis: Building a Framework. Cell 2006, 127, 679-695. [CrossRef]

171. Uppal, A.; Ferguson, M.K.; Posner, M.C.; Hellman, S.; Khodarev, N.N.; Weichselbaum, R.R. Towards a Molecular Basis of Oligometastatic Disease: Potential Role of Micro-RNAs. Clin. Exp. Metastasis 2014, 31, 735-748. [CrossRef]

172. Qian, P.; He, X.C.; Paulson, A.; Li, Z.; Tao, F.; Perry, J.M.; Guo, F.; Zhao, M.; Zhi, L.; Venkatraman, A.; et al. The Dlk1-Gt12 Locus Preserves LT-HSC Function by Inhibiting the PI3K-MTOR Pathway to Restrict Mitochondrial Metabolism. Cell Stem Cell 2016, 18, 214-228. [CrossRef] [PubMed]

173. Thayanithy, V.; Sarver, A.L.; Kartha, R.V.; Li, L.; Angstadt, A.Y.; Breen, M.; Steer, C.J.; Modiano, J.F.; Subramanian, S. Perturbation of 14q32 MiRNAs-CMYC Gene Network in Osteosarcoma. Bone 2012, 50, 171-181. [CrossRef] [PubMed]

174. Feldmann, G.; Mishra, A.; Hong, S.-M.; Bisht, S.; Strock, C.J.; Ball, D.W.; Goggins, M.; Maitra, A.; Nelkin, B.D. Inhibiting the Cyclin-Dependent Kinase CDK5 Blocks Pancreatic Cancer Formation and Progression through the Suppression of Ras-Ral Signaling. Cancer Res. 2010, 70, 4460-4469. [CrossRef]

175. Reis, E.M.; Nakaya, H.I.; Louro, R.; Canavez, F.C.; Flatschart, A.V.F.; Almeida, G.T.; Egidio, C.M.; Paquola, A.C.; Machado, A.A.; Festa, F; et al. Antisense Intronic Non-Coding RNA Levels Correlate to the Degree of Tumor Differentiation in Prostate Cancer. Oncogene 2004, 23, 6684-6692. [CrossRef] [PubMed]

176. Konoplev, S.N.; Fritsche, H.A.; O’Brien, S.; Wierda, W.G.; Keating, M.J.; Gornet, T.G.; St Romain, S.; Wang, X.; Inamdar, K.; Johnson, M.R.; et al. High Serum Thymidine Kinase 1 Level Predicts Poorer Survival in Patients with Chronic Lymphocytic Leukemia. Am. J. Clin. Pathol. 2010, 134, 472-477. [CrossRef]

177. Xu, Y.; Shi, Q.-L.; Ma, H.; Zhou, H.; Lu, Z.; Yu, B.; Zhou, X.; Eriksson, S.; He, E.; Skog, S. High Thymidine Kinase 1 (TK1) Expression Is a Predictor of Poor Survival in Patients with PT1 of Lung Adenocarcinoma. Tumour Biol. 2012, 33, 475-483. [CrossRef]

178. He, E.; Xu, X.H.; Guan, H.; Chen, Y.; Chen, Z.H.; Pan, Z.L.; Tang, L.L.; Hu, G.Z.; Li, Y.; Zhang, M.; et al. Thymidine Kinase 1 Is a Potential Marker for Prognosis and Monitoring the Response to Treatment of Patients with Breast, Lung, and Esophageal Cancer and Non-Hodgkin's Lymphoma. Nucleosides Nucleotides Nucleic Acids 2010, 29, 352-358. [CrossRef]

179. Pathak, S.; Meng, W.-J.; Nandy, S.K.; Ping, J.; Bisgin, A.; Helmfors, L.; Waldmann, P.; Sun, X.-F. Radiation and SN38 Treatments Modulate the Expression of MicroRNAs, Cytokines and Chemokines in Colon Cancer Cells in a P53-Directed Manner. Oncotarget 2015, 6, 44758-44780. [CrossRef]

180. Liu, D.; Zhang, X.; Yan, C.; Li, Y.; Tian, X.; Zhu, N.; Rong, J.; Peng, C.; Han, Y. MicroRNA-495 Regulates the Proliferation and Apoptosis of Human Umbilical Vein Endothelial Cells by Targeting Chemokine CCL2. Thromb. Res. 2015, 135, 146-154. [CrossRef]

181. Wilhelm, K.; Happel, K.; Eelen, G.; Schoors, S.; Oellerich, M.F.; Lim, R.; Zimmermann, B.; Aspalter, I.M.; Franco, C.A.; Boettger, T.; et al. FOXO1 Couples Metabolic Activity and Growth State in the Vascular Endothelium. Nature 2016, 529, 216-220. [CrossRef]

182. Yao, G.-D.; Zhang, Y.-F.; Chen, P.; Ren, X.-B. MicroRNA-544 Promotes Colorectal Cancer Progression by Targeting Forkhead Box O1. Oncol. Lett. 2018, 15, 991-997. [CrossRef]

183. Jeon, H.H.; Yu, Q.; Lu, Y.; Spencer, E.; Lu, C.; Milovanova, T.; Yang, Y.; Zhang, C.; Stepanchenko, O.; Vafa, R.P.; et al. FOXO1 Regulates VEGFA Expression and Promotes Angiogenesis in Healing Wounds. J. Pathol. 2018, 245, 258-264. [CrossRef]

184. Haig, D.; Mainieri, A. The Evolution of Imprinted MicroRNAs and Their RNA Targets. Genes 2020, 11, 1038. [CrossRef] [PubMed]

185. Haig, D. Kin Conflict in Seed Development: An Interdependent but Fractious Collective. Annu. Rev. Cell Dev. Biol. 2013, 29, 189-211. [CrossRef] [PubMed]

186. Haig, D. Imprinted Green Beards: A Little Less than Kin and More than Kind. Biol. Lett. 2013, 9. [CrossRef]

187. Patten, M.M.; Ross, L.; Curley, J.P.; Queller, D.C.; Bonduriansky, R.; Wolf, J.B. The Evolution of Genomic Imprinting: Theories, Predictions and Empirical Tests. Heredity 2014, 113, 119-128. [CrossRef]

188. Pallante, P.; Sepe, R.; Puca, F.; Fusco, A. High Mobility Group A Proteins as Tumor Markers. Front. Med. 2015, 2. [CrossRef]

189. Fusco, A.; Fedele, M. Roles of HMGA Proteins in Cancer. Nat. Rev. Cancer 2007, 7, 899-910. [CrossRef] [PubMed] 